\title{
Güney Karadeniz'de Yeni Fransız Politikası: Pascal Fourcade ve Sinop Konsolosluğu (1803-1809)
}

La nouvelle politique française dans le sud de la mer Noire: Pascal Fourcade et le Consulat de Sinop (1803-1809)

The New French Policy in Southern Black Sea: Pascal Fourcade and Sinop

Consulate (1803-1809)

\section{Özgür Yilmaz}

\section{OpenEdition \\ Journals}

Édition électronique

URL : https://journals.openedition.org/ceb/5329

DOI : $10.4000 /$ ceb.5329

ISSN : 2261-4184

Éditeur

INALCO

Référence électronique

Özgür Yilmaz, « Güney Karadeniz'de Yeni Fransız Politikası: Pascal Fourcade ve Sinop Konsolosluğu

(1803-1809) », Cahiers balkaniques [En ligne], 42 | 2014, mis en ligne le 06 juin 2014, consulté le 07

juillet 2021. URL : http://journals.openedition.org/ceb/5329; DOI : https://doi.org/10.4000/ceb.5329

Ce document a été généré automatiquement le 7 juillet 2021.

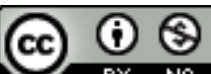

Cahiers balkaniques est mis à disposition selon les termes de la Licence Creative Commons Attribution - Pas d'Utilisation Commerciale 4.0 International. 


\section{Güney Karadeniz'de Yeni Fransiz Politikas1: Pascal Fourcade ve Sinop Konsolosluğu (1803-1809)}

La nouvelle politique française dans le sud de la mer Noire: Pascal Fourcade et le Consulat de Sinop (1803-1809)

The New French Policy in Southern Black Sea: Pascal Fourcade and Sinop

Consulate (1803-1809)

\section{Özgür Yilmaz}

Devrim ve Imparatorluk dönemlerinde Levant'ta konsolos olmak hiç kolay bir meslek değildi. ${ }^{1}$

\section{Giriş}

Osmanlı Devleti'nin Avrupa'daki en kadim müttefiki olarak Fransa'nın Osmanlı coğrafyası ile çok önemli siyasi ve ticari ilişkileri bulunuyordu. Kanuni döneminde iki ülke arasındaki ilişkilere paralel olarak gelişen ve ilk olarak 1535 tarihli bir ticaret antlaşması ve Fransa'ya verilen imtiyazlar ile başlayan Osmanlı-Fransız ticari ilişkileri 1740 tarihli bir başka imtiyaz anlaşmasıyla daha da genişlemiş ve Fransa, Osmanlı ülkesindeki ticarette en önemli pay sahibi ülke konumuna geldiği gibi siyasal ve kültürel nüfuzunu arttırarak Yakın Doğu'nun en etkin gücü haline gelmiştir. ${ }^{2}$ Fakat Osmanlı ülkesindeki Fransız ticareti ciddi bir rakip olarak İngiltere ile karşılaşmakta gecikmedi. İlk olarak 1580'de Sultan Murad II döneminde ilk imtiyazı alan İngilizler, 17. yüzyılda bu imtiyazın devamı niteliğindeki ahidnameler ile ticaretin tabi olacağı şartlar tespit edildi. Böylece İngilizler Osmanlılar ile olan ticari münasebetlere Venedik ve Fransa'dan epey bir zaman sonra başlasa da bu ülkelerin önüne geçmeyi başardılar. Bunların yanında Fransa'nın Levant'taki konumunu belirlemesi bakımından bu topraklarda Fransız ticaretini etkileyen en önemli gelişme Fransız İhtilali oldu. 1789'dan itibaren Fransa'nın Osmanlı ülkesine yaptığı ihracatın oranı beşte iki 
oranında azalma gösterdi. ${ }^{3}$ Osmanl1-Fransız ilişkilerine asıl darbeyi vuran gelişme ise Napolyon'un Mısır Seferi'ydi. Mısır'daki işgal döneminde (1798-1802) iki ülke arasındaki siyasi münasebetler askıya alındığı gibi Osmanlı-Fransız ticareti durma noktasına geldi. Bu ortamda Mısır'ın boşaltılmasından sonra Fransızların en önemli amacı Osmanlı ülkesindeki eski ayrıcalıklarını yeniden kazanmak olmuştur.

2 Mısır'ın işgali ile bozulan Osmanlı-Fransız ilişkilerinin düzeltilmesi maksadıyla Fransız hükümeti, Paris Sefiri Ali Efendi vasıtası ile bazı teşebbüslerde bulunsa da, Ali Efendi her firsatta Fransızların Mısır'ı tahliye etmelerini şart koymuştu. Bu bağlamda Talleyrand ile Ali Efendi arasında 9 Ekim 1801'de bir ön barış antlaşması imzalanmıştı. ${ }^{4}$ Mısır'ın işgali öncesindeki dostluk ve ilişkilerin yeniden ihya edilmesi amacıyla temelde Mısır'ın tahliyesini taahhüt eden anlaşma maddeleri ile Fransa, Osmanlı devleti ile tekrar ticari münasebetler kurmak ve ilerde de Karadeniz'i Fransız gemilerine açtırmak istiyordu. Bu maksatla Bonaparte General Sebastiani'yi İstanbul'a gönderdi. Sebastiani'ye ${ }^{5}$ verilen talimatlarda Fransa'nın şimdilik Türkiye üzerindeki emellerini gerçekleştiremediği belirtilerek Hindistan yolu üzerindeki nüfuzunu yayarak ticaretini geliștirmesi gerektiği ifade ediliyordu. ${ }^{6}$ Bunun yanında Rusya ve İngiltere'ye karşı güçlü bir Türkiye'nin Fransa'nın yararına olacağı ifade edilmekteydi. ${ }^{7}$ Hatta Osmanlı-Fransız barış antlaşmasını müzakere etmek üzere Fransa'ya gönderilen murahhas Galib Efendi, Bonapart'in, Rusya gibi Fransa'nın da Karadeniz'de ticaret yapması konusundaki ısrarına tanık olmuştu. Galib Efendi bu konuda hem Babıali'nin onayını almak gerektiğini hem de bu gelişmeye Rusya'nın muhalefet edeceğini ifade etmiştir. Galip Efendi'nin Fransa'nın taleplerine ilişkin raporları İstanbul'a ulaşınca, Fransızların bu talebi incelenmiş ve daha önce İngiltere'nin tekliflerine bile reddedilen bu ticaret hakkının, Fransa'yı gücendirmemek ve onunla bir an önce barış antlaşması yapmak için bu ülkeye tanınmasına karar verilmiștir. ${ }^{8}$ İstanbul'dan gelen bu talimatlar doğrultusunda Galip Efendi ile Talleyrand arasında 25 Ekim 1802'de Türk-Fransız Barış antlaşması imzalanmış ve bu şekilde Karadeniz'de Fransız konsolosluklarının tesis edilmesi için de gerekli zemin de hazırlanmıştır. ${ }^{9}$

1802 Anlaşması sonrasında Fransız dışişleri Karadeniz'de yeni konsolosluklar tesis etme yönünde adımlar atsa da asıl uğraşı Fransız Devrimi'nin diplomatik temsilciliklerinin yeniden organize edilmeleriydi. Bu bakımdan ihtilalden 1803 yilına kadar devam edecek olan bir dönemde Fransa'nın dünyanın değişik bölgelerindeki konsoloslukları zor bir dönem geçirse de özellikle Levant bölgesindekiler, Napolyon'un Mısır Seferi'nin sonrasında bu seferin sonuçları daha dramatik bir şekilde hissetti. Zira kesilen diplomatik münasebetler sonucunda Osmanlı hükümetinin emriyle konsoloslar ve diğer Fransızlar tutuklanmış ve mallarına ihtiyati olarak el konulmuştu. ${ }^{10} 25$ Haziran 1802'deki Osmanlı-Fransız antlaşmasından sonra Général Brune'ün İstanbul elçiliğindeki faaliyetlerinden biri de Mısır seferinden sonra oldukça zor durmada kalan limanlarda yer alan konsoloslukların yeniden organize edilmesiydi. Levant bölgesindeki konsoloslukların yeniden tesis edilmesi kısmen Osmanlı Fransız ilişkilerinin kesilmesinde önce Directoire döneminde uygulamaya konulan bir plana göre gerçekleştirildi. Konsolosluk kurumunun kayda değer bir şekilde güçlendirilmesi sekiz yeni konsolosluğun tesis edilmesiyle beraber Karadeniz kıyılarında gerçekleşti. Bunların arasinda Rus topraklarında yer alan Odesa ve Sivastopol'u saymazsak Avrupa'da Tuna'daki preslikler ve Rus imparatorluğu arasında yardımcı bir yer Olarak Yaş genel bir konsolosluğa yükseltildi. Bükreş de bir alt komiserlik haline getirildi. 
Bunun dişında Varna ve Kalas'ta birer konsolosluk tesis edildi. Anadolu sahillerinde ise Sinop merkezli olmak üzere Ereğli ve Trabzon'da konsolosluklar tesis edildi. ${ }^{11}$

4 Fransızların konsolosluk açacakları yerin seçiminde genel olarak genel konsolos (consulat général) ve konsoloslar, elçilerin imparatorluğun başkentinde ikamet etmesi gibi valilerin yerleşik olduğu vilayet merkezlerinde ikamet etmeyi tercih etmekteydiler. Bununla birlikte bu kural bölge ticaretinin gerekleri doğrultusunda bazen vilayet merkezinin uzağında da olabiliyordu. Fakat genel olarak konsoloslar liman şehirlerinde yerleşik bulunuyorlardı. ${ }^{12} \mathrm{Bu}$ bağlamda Fransızların Güney Karadeniz'deki temsilciliklerini bu şekilde Sinop merkezli olarak tesis etmeleri 19. yüzyılın koşullarına uygun bir tercih değildi. Trabzon, İran ile Karadeniz arasında bir transit ticaret merkezi olsa da, Sinop ve Ereğli eski dönemlerdeki önemlerinin oldukça uzağındaydılar. ${ }^{13}$ Sinop'taki genel komiserlik tercihi, her ne kadar Sinop iyi bir limana ev sahipliği yapsa da ilerde Fourcade'ın yazışmalarında da görüleceği gibi şehrin, ticaret potansiyeli yüksek bir transit noktası haline gelmesi önündeki engeller bakımından Fransız dışişleri için istenilen neticeyi ortaya koymamıştı. Bu bakımdan Sinop'un yerini tayin etmemiz açısından aşağıdaki tablo da 1803 yılı itibarı ile Fransızların Osmanlı coğrafyasında diplomatik temsilciliklerinin yer seçimi konusunda bazı fikirler verebilir:

\section{Yüzyılın Başlarında Osmanlı İmparatorluğu'nda Fransız Konsoloslukları}

Kaynak: Almanachs Royaux 1803, s. 219-220.

\begin{tabular}{|c|c|c|c|c|c|}
\hline \multicolumn{2}{|c|}{ Avrupa, Türkiye'si/Rumeli } & \multicolumn{2}{|c|}{ Ege Adaları ve Kıbrıs } & \multicolumn{2}{|c|}{ Asya Türkiye'si } \\
\hline $\begin{array}{l}\text { Konsolosluk } \\
\text { Merkezi }\end{array}$ & $\begin{array}{l}\text { Konsolosluğun } \\
\text { Statüsü }\end{array}$ & $\begin{array}{l}\text { Konsolosluk } \\
\text { Merkezi }\end{array}$ & $\begin{array}{l}\text { Konsolosluğun } \\
\text { Statüsü }\end{array}$ & $\begin{array}{l}\text { Konsolosluk } \\
\text { Merkezi }\end{array}$ & $\begin{array}{l}\text { Konsolosluğun } \\
\text { Statüsü }\end{array}$ \\
\hline Kerson & $\begin{array}{l}\text { Genel } \\
\text { Komiserlik }\end{array}$ & Hanya & Komiserlik & Ereğli & Alt Komiserlik \\
\hline Kalas & Alt Komiserlik & Kandiye & Alt Komiserlik & Sinop & Komiserlik \\
\hline Varna & “ & $\begin{array}{l}\text { Anabolu } \\
\text { (Mora) }\end{array}$ & “ & Trabzon & Alt Komiserlik \\
\hline Çanakkale & Alt Komiserlik & Koron (Mora) & Komiserlik & İzmir & “ \\
\hline Yaş & $\begin{array}{l}\text { Genel } \\
\text { Komiserlik }\end{array}$ & Sakız & “ & Mascate & Komiserlik \\
\hline Atina & Alt Komiserlik & Rodos & Alt Komiserlik & Basra & “ \\
\hline Selanik & $\begin{array}{l}\text { Genel } \\
\text { Komiserlik }\end{array}$ & Larnaka & Komiserlik & Halep & $\begin{array}{l}\text { Genel } \\
\text { Komiserlik }\end{array}$ \\
\hline Bükreş & Alt Komiserlik & & & Lazkiye & Alt Komiserlik \\
\hline
\end{tabular}




\begin{tabular}{|l|l|l|l|l|l|}
\hline & & & & Trabluş̧am & Komiserlik \\
\hline & & & & Akka & “ \\
\hline
\end{tabular}

Her ne kadar Karadeniz'in güney kıyılarında Fransızların konsolosluk tesis etme süreci 19. yüzyılın başlarında gerçekleşse de aslında Karadeniz'deki Fransız ticaret teşebbüsleri daha eskiye kadar gitmektedir. 18. yüzyılda Fransızların hazırladıkları pek çok değişik proje arasında İngiltere'ye karşı yeni ticari sahalar oluşturma ve buralardan ucuz hammadde temin etmeye yönelik olanlar vardı. Isște bu projeler için Osmanlı ülkesi ve özellikle de Karadeniz Fransız ticari beklentilerinin çok yüksek olduğu bir yerdi. Bu amaçla 14. Louis'den Fransız Devrimi'ne kadar Fransız diplomat, seyyah ve tüccarlar pek çok girişimde bulundu. 1774 Küçük Kaynarca Antlaşması sonrasında Rusların Karadeniz'de ticaret ve seyir yapma hakkı kazanması da Fransızlara bu yönde umut vaad ettiği gibi endişeler de yaratmıștı. Bu bakımdan özellikle Kırım devrim öncesi dönemde Fransa-Karadeniz ilişkilerinin odak noktası haline geldi. Bu dönemdeki Kırım merkezli girişimler de 19. yüzyılda daha büyük bir ivme kazanan Karadeniz'deki Fransız varlığının da temellerini teşkil etti. ${ }^{14}$ Rusların Küçük Kaynarca Antlaşması ile beraber Karadeniz'de önemli ticari kazanımlar elde etmesi ve arkasından da bu hakkın 1784 yllında Avusturya'ya verilmesi diğer batılı devletlerin de dikkatini çekti. Bu maksatla Fransız hariciyesi de önce Saint Priest arkasından da Choiseul-Guuffier'den aynı hakları elde edebilmek için girişimde bulunma konusunda talimat almıştı. Fakat Fransa ile Karadeniz arasındaki ticaret sadece Kerson'daki Fransız ticareti ile sınırlı kald.${ }^{15} \mathrm{Bu}$ bağlamda Fransız devrimi ve arkasından Fransa'nın Mısır'ı işgali Fransa'nın Karadeniz'de ticaret yapabilmek için daha önceki tüm hamlelerini de durdurdu. Bunun yanında Rusya Yaş Antlaşması ile Karadeniz'deki topraklarını genişletirken Fransa'ya karşı Osmanlı-Rus ittifakı döneminde de Rus gemileri boğazları serbestçe geçme hakkına sahipti. ${ }^{16}$ Daha sonra bu hakkın Fransızlara da tanınması aslında Rusların hoşlanmadığı bir gelişme olmuştu. Rusya, Fransa'nın Karadeniz'deki ekonomik ve politik rekabetine şüphe ile yaklaşmaktaydı. Rus çarı bir Rus gölü olarak gördüğü Karadeniz'deki Fransız varlığını kendi haklarına karşı bir ihlal olarak telakki ediyordu. Bu nedenle İstanbul'daki Rus elçisi İtalinski'nin Karadeniz'e açılmak isteyen Fransız gemilerini engellemek için elinden geleni yapmaktayd.$^{17}$ Nitekim aynı politika Sinop'ta Fourcade'ın karşısına da çıkmakta gecikmeyecektir. şehirdeki Rus konsolosu Konuchenco'nun ${ }^{18}$ entrikaları 1806 yılına kadar Fourcade'ın karşılaş̧ı̆̆ı en önemli zorluklardan biri olmuştur.

6 Fransız dişişlerinin Güney Karadeniz'deki bu konsolosluk tercihlerinin Osmanlı İmparatorluğu'nun güncel koşulları ile uygunluğu çok geçmeden ortaya çıtı. Zira sadece dış ilişkilerdeki dalgalı eğilim açısından değil imparatorluğun dâhili idaresindeki bir bunalım dönemi de özellikle Güney Karadeniz'deki yeni konsoloslukları en çok etkileyen koşullar oldu. Bunların yanında Fransa bu yerel koşulları ve belki de en önemlisi Karadeniz'de kendinden başka bir güç istemeyen Rusya'nın politikalarını da hesaba katmak zorundaydı. Bu etkenler Sinop ve Ereğli'deki konsoloslukların çok geçmeden kapanmasına ve Trabzon'daki alt komiserliğin de bir konsolosluğa yükseltilmesine neden oldu. İşte Osmanlı-Fransız ilişkilerinin yeniden tesis edildiği bu yumuşama döneminin bir neticesi olarak Sinop'ta açıldığını gördüğümüz bu konsolosluk çalışmamızın ana konusunu teşkil etmektedir. Çalışma 
Fourcade'ın Sinop'taki görevi ve konsolosluğunun ilk Dönemleri; Tayyar Mahmud Paşa ile olan ilişkileri; Rus Konsolosu Konuchenco'nun faaliyetleri; Tayyar Mahmud Paşa sonrası gelişmeler; Fourcade'ın bilimsel çalışmaları ve Sinop'tan kaçışını inceleyen başlıklardan oluşmaktadır.

7 Sırası gelmişken çalışmamızın kaynakları hakkında da burada bilgi vermek yerinde olacaktır. Bugüne kadar Fourcade ve konsolosluğu hakkında yapılan çalışmalar daha çok onun Sinop'taki görevi sırasında bölgede gerçekleştirdiği arkeolojik çalışmalar ve bu çalışmalara ilişkin olarak hazırladığı raporların, "mémoire" Orta Karadeniz Bölgesi'nin antik tarihi hakkındaki değerleri vesilesi ile değerlendirilmiştir. ${ }^{19}$ Bunların yanında Fourcade'ın konsolosluğunu Trabzon ve Ereğli'deki konsoloslar ile değerlendiren daha geniş çalışmalar da vardır. ${ }^{20}$ Fakat bu çalışmaların da Fourcade'ın konsolosluğunun tam olarak değerlendirilmesi açısından bazı eksiklikleri bulunmaktadır. Hem bu eksikliklerin giderilmesi hem de özelde Sinop tarihi genelde de Osmanlı-Fransız ilişkilerinin 19. yüzyılın başlarında bir ayağını ortaya koyması açısından bu çalışma Fourcade'ın Sinop konsolosluğunu değerlendirme amacındadır. Çalışmanın temel Kaynakları Fransız Dışişleri Bakanlığı Arşivlerinin Paris (La Courneuve) ve Nantes'taki arşiv merkezlerinde yer alan belge koleksiyonlarıdır. Bilindiği gibi 1803 yılında kurulan konsolosluk 1812 yllında ilga edilmişti. Bu bakımdan bu dokuz yıla ilişkin olarak Paris'teki merkezde "Correspondance consulaire et commerciale" tasnifi altında Sinop'a ait bir karton "Sinope 1801-1811" yer almaktadır. Fakat bu karton 1802-1803 yılına dair birkaç yazışmadan sonra 1804-1809 yılı arasındaki yazışmaları içermektedir. ${ }^{21}$ Dolayısıyla konsolosluğun ilk yılı ile Fourcade'ın konsolosluktan ayrıldığ 1809 'dan sonraki 3 yıla ilişkin raporlar bu tasnifte yer almamaktadır. Bunun yanında Nantes'taki arşiv merkezinde de Sinop ile ilgili bir karton yer almaktadır. ${ }^{22}$ "Correspondance avec le poste de Sinope" başlı̆̆ı ile 1803-1812 yıllarını arasını kapsayan bu karton Paris’teki tasnife göre konsolosluğun yaptığı ilk yazışmaları, yani 1803 yılı başı ve 1804 yılı yazışmalarını içermesi bakımından önemlidir. Bunların yanında yine Paris'teki arşivde "Mémoires et Documents" tasnifinde Fourcade'ın gerek Sinop gerekse de bölgede gerçekleştirdiği gezilere ilişkin bazı ayrıntılı raporlar yer almaktadır. ${ }^{23}$ Biz de çalışmamızda bu kaynaklardan hareketle Fourcade'ın Sinop konsolosluğunu, konsolosluğun nasıl bir ortamda kurulduğu ve Fourcade'ın karşılaştığı zorluklar çerçevesinde inceleyerek Fourcade'ın Sinop konsolosluğunun neticelerini inceleyeceğiz.

\section{Fourcade'ın Görevi ve Sinop Konsolosluğunun Başlaması}

8 Fourcade 1769 'da Pau'da doğdu. Sinop'taki konsolosluğu süresince de görüleceği gibi her an etkisinde olduğu iyi bir klasik eğitimi aldı. Daha sonra Paris'e gitti. Burada devrim hareketlerine katıldı. 1795 'te Akka'ya konsolos tayin edildi; ${ }^{24}$ fakat bu görevine gitmedi. Aynı sene Hanya'ya konsolos olarak atandı. Fransızların Misır Seferi döneminde Eylül 1898'de burada hapsedildi ve burada eşi ve ilk çocuğu ile 13 ay tutuklu kaldı. Daha sonra İstanbul'a getirildi ve burada da tutukluluk hali devam etti. Ocak 1801'de Fransa'ya döndü ve 1802 Osmanlı-Fransız barışı doğrultusunda Sinop'a konsolos olarak tayin edildi. ${ }^{25}$ 
Sinop'taki genel komiserliğine bağlı olarak Ereğli ve Trabzon'da da birer alt komiserlik tesis edilmesiyle Ereğli'ye Louis Allier, ${ }^{26}$ Trabzon'a da Pierre Dupré tayin edildi. 2 Aralık'ta Toulon'dan General Brune ile yola çıkan bu üç konsolos 6 Ocak 1813'te İstanbul'a vardı. Fakat bu üç konsolosun da Osmanlı hükümetinden gerekli izinleri alabilmek ve görev yerlerine gitmek için 1803'ün güzünü beklemeleri gerekti. ${ }^{27}$ Allier 13 Ekim'de Ereğli'ye ${ }^{28}$ Dupré de Eylül'ün sonlarında İstanbul'dan hareketle Ekim'in ortalarına doğru Trabzon'a ulaştı. ${ }^{29}$ Fourcade ise 9 Ekim'de İstanbul'dan hareket ederek 14 Ekim'de Sinop'a vard1. ${ }^{30} \mathrm{Bu}$ konsoloslar içinde en iyi karşılanan da Fourcade oldu. Ereğli'de Allier şehrin idarecisi olan İbrahim Bey tarafından hiç iyi karşılanmadı ve neredeyse tutuklu olarak kaldığı Ereğli'den 1803'ün Aralığında ilk Rus Gemisi ile İstanbul'a kaçtı ve Ereğli konsolosluğu kapatıldı. Dupré de eyalet merkezi olan Trabzon'da uzun süre kabul görmeyi bekledi. ${ }^{31}$ Bu konuda Fourcade, Tayyar Mahmud Paşa nezdinde girişimlerde bulunarak Duprénnin konsolosluğunu kurmasına yardımcı olunması için uzun süre uğraş vermiştir. Aslında bu üç konsolostan belki de kendilerine yüklenen görevi en iyi icra edecek kişi Dupré'ydi. Zira Dupré İstanbul'daki elçilik bünyesine dâhil olmadan Yunanistan'daki bir Fransız ticaret görevlisi ve Arnavutluk'ta da kereste tüccarlığı yapmıştı. ${ }^{32}$ Gerçekten de konsolosluğun kurulması sürecinde karşılaştığı ilk zorluklara rağmen Dupré 1947 yılına kadar yaşayacak olan Trabzon Fransız Konsolosluğu'nun temelini atmıştı.

10 Karadeniz'e atanan bu konsolosların en önemli görevleri Fransa'nın çıkarlarını ve Fransız ticaretini korumaktı. Bu itibarla bu görevliler Napolyon tarafından özellikle istenmekteydiler. Fakat konsolosların askeri, diplomatik ve denizcilikle ilgili olarak da aracı bir rolleri bulunuyordu. Konsoloslar Anadolu sahilleri için Rusya'nın faaliyetlerini, burada Çapanoğulları ile Canikli arasındaki mücadeleye gözetleyeceklerdi. Trabzon'daki konsolos Dupré ise özellikle Karadeniz'in kuzey doğusu, Gürcistan, Erzurum, Kars ve İran'daki gelişmeleri takip edecekti. Fakat Bilici'nin de belirttiği gibi, bu şekilde bir anlayış ile değişik yerlere tayin edilen konsoloslar Anadolu'daki anarşi ortamında hem Paris'te Dışişleri Bakanlığı hem de İstanbul'daki elçilik tarafından kaderlerine terkedilmişlerdi. Zira gerek yerel koşullarda gerekse de iki ülke ilişkilerindeki dalgalanmalar bu temsilciliklerden istenilen neticeyi almak bir süre daha beklemeyi gerekli hale getirdi. ${ }^{33}$

11 Burada Sinop'un bir konsolosluk merkezi olarak tercih edilmesinin Sinop'un koşullarına uygun bir tercih olup olmadığı üzerinde de durmak gerekmektedir. Bilindiği gibi Sinop Osmanlı-Rus savaşlarından en çok etkilediği yerlerden biriydi. Karadeniz'in tamamen Osmanlı egemenliğinde olduğu dönemlerde burada cereyan eden kuzey-güney arasındaki ticari münasebetlerin en çok katkı yaptığı şehirlerden biri de Sinop'tu. Özellikle Kırım ile olan ticarette Sinop, Anadolu ürünleri için bir çıkış kapısı niteliğindeydi. Fakat Kuzey Karadeniz'de Rusların gittikçe genişleyen hâkimiyeti Karadeniz limanları arasındaki ticarete etki ettiği gibi özellikle Sinop ve Trabzon gibi kuzey limanlarıyla bağlantılı olan şehirlerin ticaretleri içinde bir gerileme dönemini başlattı. En azından yüzyılın başlarında bu şehirlerin nüfusları bu gerilemeye ilişkin olarak bize bazı fikirler verebilir. Trabzon'daki Fransız konsolosu Dupré şehrin nüfusunu hakkında 1803 yılı için 16,000 olarak verirken ${ }^{34}$ diğer kaynaklar da 10,000 civarında bir nüfustan bahsetmektedir. ${ }^{35}$ Fakat Fourcade'ın konsolosluğu döneminde şehri ziyaret eden Trabzon Fransız konsolosu Dupré'nin oğlu Adrian Dupre'ye göre Sinop'un nüfusu 7-8,000 civarındayd $1 .^{36} 1808$ yılında Sinop'a uğrayan Tancoigne ise büyük bir kısmını kele içinde yerleşik olan Türklerin oluşturduğu 
Sinop'un nüfusunu 12.000 olarak tahmin etmektedir. ${ }^{37} \mathrm{Bu}$ konudaki güvenebileceğimiz en önemli kaynak bizzat Fransiz konsolosu Fourcade'tır. Fourcade, 6 Germinal An 12 tarihli raporda savaşlardan harabe haline gelen ve tüm evlerin kulübe şeklinde olduğu Sinop'ta, sefalet ve fakirlik içinde yaklaşık 2,000 kişinin yaşadığını ifade ediyordu. ${ }^{38}$ Muhakkak bu birbirinden farklı rakamlar arasındaki tutarsızlığı dikkate almak gerekir; fakat bunların içinde Sinop'ta en fazla kalan ve şehri en iyi tanıyanın bizzat Fourcade olduğunu hesaba katarsak onun vermiş olduğu bu düşük rakam üzerinden yukarıdaki değerlendirmelerimizi desteklemek doğru görünmektedir. Üstelik bu düşük nüfus Fourcade'in konsolosluk döneminde de azalmaya devam edecektir. ${ }^{39}$ Bundan dolayı Fourcade'ın, Sinop'un ticari potansiyelini değerlendirirken "Sinop bir ticaret yeri olarak hiçbir kaynak sunmamaktadır. şehir sadece Anadolu ve İran ile yapılacak ticarette bir merkez konumundadır" şeklindeki ifadeleri de Sinop'un öneminin şehrin üretim ve tüketim potansiyelinden değil, özellikle transit bir ticaret mahalli olmasından kaynaklandığını belirtiyordu. ${ }^{40}$

İşte bu şekilde bir potansiyele sahip olan Sinop'a konsolos konsolos/genel komiser olarak tayin edilen Fourcade gerek Sinop'a yolculuğu gerekse de şehirde karşılanması hakkında değişik raporlar hazırladı. Yolculuğuna ilişkin olarak hazırladığı raporda Sinop'a kadar olan önemli limanlar hakkında bilgiler verdi. ${ }^{41}$ Fourcade Ekim ayının ortalarında meraklı bir kalabalığın kendilerini beklediği ve iyi bir şekilde karşılandığı Sinop'a ulaştı. ${ }^{42}$ Sinop mütesellimi Fourcade'ı iyi bir şekilde karşıladı. Fakat Fourcade'ın Sinop'a varır varmaz karşılaştığı en önemli engel şehirdeki Rus konsolosu Konuchenco'ydu. ${ }^{43}$ Konuchenco Fourcade'ı her firsatta şehir idarecileri ile olan ilişkilerinde engellediği gibi konsolosluk binası seçiminde de müdahil olmuştu. Fourcade, Sinop'taki ilk günlerini anlattığı raporunda konsolosluk binası olarak kullanılabilecek ve eski Sinop ağalarından birine ait limana yakın bir oldukça geniş ve makul bir ev olduğunu; fakat buranın tahsis edilmesi konusunda Konuchenco'nun müdahil olduğunu belirtiyordu. Fakat Fourcade buraya yerleşmek için Sinop müteselliminin Tayyar Paşa'dan alacağı onayı beklemek ve yine de mecburen Rus meslektaşının evinde ikamet etmek zorunda kalacaktı. ${ }^{44}$

Fourcade raporlarında en önemli görev olarak, Fransızların Karadeniz'de ticaret hakkı kazanmalarıyla beraber Fransız malları için yeni pazarlar elde etmek, Anadolu'daki hammaddeleri almak ve Trabzon, Samsun ve Sinop'ta Anadolu ve İran'dan gelecek olan mallar için antrepolar kurmaktan bahsetmekteydi. ${ }^{45} \mathrm{Bu}$ görevle Sinop'a gelen Fourcade ilk olarak ticari altyapı hakkında incelemeler yapma gereği duymuş olmalıdır. Bu hususta raporlarında değindiği en öncelikli konu da limanların durumuydu. Fakat konsolosa göre firtınalı bir havada İstanbul'dan Sinop'a gelen konsolos için sahillerin planlarını çizmek, limanların derinliklerini ölçmek imkânsızdı. Bu nedenle Fourcade daha sonra bu limanları incelemenin en önemli çalışmalarından biri olduğunu belirterek Ereğli, Amasra, Kytros (Cide), İnebolu, Hefani, Sinop, Gerze ve Samsun limanlarını görmenin ve bunların planlarını yapmanın çok gerekli olduğunu ifade etmiştir. Konsolosa göre Fransız gemileri sık sık bu limanlara uğrayacaksa bu gemilere oldukça geniş olan bu sahillerde sığınabilecekleri yerleri göstermek gerekiyordu. $\mathrm{Bu}$ doğrultuda Fourcade, Fransız denizciliği için Sinop ve çevresindeki denizcilik hakkında bilinmesi gerekenler hakkında küçük bir rapor hazırladı. ${ }^{46}$ 


\section{Sinop: İkinci İskenderiye veya Anadolu'nun Bağdat'ı?}

14 genellikle vilayet merkezleri tercih edilmekteydi. Bunun yanında ticaretin bir gereği olarak ağırlığın da önemli limanlara verildiği ve konsolosluk teşkilâtının limanlarda yoğunlaştığı görülmektedir. Sinop'un genel bir konsolosluk olarak seçilmesi bu kıstasa uygundu. Buna karşın Sinop Osmanlı idari teşkilatında sadece bir kaza statüsündeydi. Zira Sinop Anadolu Eyaleti'nin Kastamonu Sancağı'na bağlı bir kazaydı ve şehrin bu idari statüsü Tanzimat dönemine kadar devam etti. ${ }^{47}$ Her ne kadar vilayet merkezine olan bu uzaklık, zaman zaman konsoloslara bir serbestlik sağlasa da, özellikle Tayyar Paşa ile ticari ilişkiler konusunda bağlantı kurmaya çalışan Fourcade için bir engeldi. ${ }^{48}$ Sinop'un içinde yer aldığı bu idari yapıya karşın Fourcade'ın planlarının bir gereği olarak en çok Karadeniz'in güney sahillerini içeren Trabzon Eyaleti Valisi Tayyar Paşa ve onun idaresinden bahsetmesi de bu durumu ortaya koymaktadır.

Böyle bir ortamda Sinop'a gelen Fourcade'in ilk raporları da Sinop ve idari ve ticari yapısı üzerine olmuştur. Konsolos 24 Vendémiaire An 12 tarihli raporunda genel olarak bölgenin siyasi yapısı ve Tayyar Mahmud Paşa'nın bölgedeki etkinliğine ilişkin olarak Sinop'taki Rus konsolosu olarak görev yapan Konuchenco'dan aldığı bilgileri raporunda elçiliğe iletti. ${ }^{49}$ Fakat konsolosluk döneminde Sinop'un durumunu daha iyi tahlil edebilmemiz için Fourcade'ın daha sonraki yazışmalarına bakmak gerekir. Fourcade konsolosluğun bu ilk dönemlerinde bölgedeki siyasi hadiseleri ve ticari meselelerin yanında başka konularda da incelemeler yapıyordu. Bu konuda 26 Pluviose An 12 tarihli raporunda, elçiliğe gönderilmek üzere Sinop hakkında ayrıntılı bir rapor, «mémoire statistique sur la ville de Sinope \& des environs, état physique \& moral de pays, relation établies au possible avec l'intérieur de l'Asie, description des restes d'antiquité " hazırladığını yazıyordu. Fourcade'ın gönderceği belgeler arasında bölgedeki ticaret ve Mahmud Paşa ile ilgili bilgiler, Sinop yarımadasının planı ve haritası, Akliman'ın haritası ve Sinop'un 10 mil batısında ve İnceburun'un güneydoğusunda yer alan öteki limanların haritaları ki bunlar içinde en önemlisinin de şimdiye kadar bir haritası olmayan Akliman'ın olduğunu belirttiği bazı plan ve bilgiler hazırlamaktaydı. ${ }^{50}$ Daha sonraki yazışmalarında Fourcade benzer konular üzerinde durmaya devam etmiştir. Fourcade, Sinop üzerine hazırladığı diğer bir raporda, Sinop'un yarımada üzerindeki yerleşimi, kalenin ve surların durumundan bahsetmektedir. Bu rapora göre yarımada iki körfez ortaya çıkarmakta ve bunlardan sağ tarafta kalan da mükemmel bir demirleme yeri sunmakta ve limanın kayalık tarafında kalan mahal de küçük gemiler için uygun bir durumdayd1..$^{51}$ Limanda yeni yapılan savaş gemilerinin olduğunu da belirten Fourcade, Sinop tersanesinin Osmanll-Rus savaşında aktif olduğunu, yarımadanın ise beş batarya tarafından muhafaza edildiğini de belirtmektedir. ${ }^{52}$ şehrin iktisadi durumu ise iyi değildi ve iaşenin iyi olmadı Sinop'ta arpa, buğday ve arpa fiyatlarının günden güne yükseliyordu. şehrin idaresine de değinen Fourcade şehrin mütesellim tarafından idare edildiği ve ağalardan sonra şehirde en etkili kişinin de kadı olduğunu ifade eder. ${ }^{53}$ Fourcade'ın daha sonraki yazışmalarında da en çok karşılaştığımız idareciler mütesellim ve kadıydı.

Fourcade'ın yüksek beklentiler ile başladığı görevinde bu projeleri hemen uygulamaya koymasının önünde bazı zorluklar yer almaktaydı. Bu süreçte karşılaştı̆̆ı en cağı zorluklardan biri de Sinop'un ticaretine dair bilgi eksiklikleriydi. Elçiliğe yazdığı ilk 
raporlarda Sinop’a yeni geldiğini ve ticari konular hakkında henüz yeterinde bilgi alamadığını ifade ediyordu. Buna rağmen Fourcade'ın Anadolu ve İran'ın en önemli ticari üssü olarak belirttiği Sinop'un geleceğine ilişkin çok ciddi projeleri vardı. Bu maksatla bölgenin Fransız ticareti için sunacağı imkânları tayin etmek için Tokat, Amasya ve hatta Ankara'nın ticari durumu hakkında kendisine gelecek mektupları beklemekteydi. Fakat bu yazışmalar Fourcade'ı memnun etmemiş olacak ki bu sınırlı bilgi ile bölge ticaretinden çok umutlu olmadığını; bu konudaki en iyi yolun kendisinin Sinop dışına çıkarak bizzat seyahatler yaparak Sinop ve çevresinin sunacağı imkânları görmek olduğunu ifade etmekteydi. Bu bağlamda Fourcade'ın konsolosluğunun ilk dönemlerinde Kastamonu ve diğer şehirlere yapmak istediği seyahatleri özellikle Rus meslektaşı Konuchenco'nun entrikaları ile ertelenmek zorunda kalmıştır. ${ }^{54}$

Fourcade'ın bu Sinop'un durumu hakkındaki umutsuz hali aslında yersiz değildir. Sinop her ne kadar doğal kaynaklar bakımından zengin olsa da nüfusu günden güne azalan; buna karşın vergileri sürekli artan bir şehir olarak takası yapılabilecek bir ticari eşya sunmadığı gibi üretim ve endüstrinin de olmadı̆̆ı bir yerdi. Fourcade, bütün bu olumsuzluklara karşın Sinop'un limanı sayesinde önemli bir ticari merkez olacağına inanıyordu. Hatta romantik bir değerlendirme ile Sinop'un antik dönemlerde olduğu gibi Anadolu'nun antreposu olabileceğini yazıyordu. Bu doğrultuda ülkenin iç kısımlarında karışıklık ortadan kalkması durumunda Fransız üreticiler rahat bir şekilde seyahat edebilecek ve eyaletlerin ve şehirlerin ileri gelenlerinin güvenlerini kazanabileceklerdi. Konsolos Fourcade özellikle bu konuda elde edebileceği tüm bilgileri toplamak ve karşılaşacakları zorluları belirlemek için çalıştı̆̆ını ifade ediyordu. ${ }^{55} \mathrm{Bu}$ maksatla Fourcade Sinop'un ticari önemine ve geleceğine dair daha ayrıntılı raporlar hazırlamaya başladı. Mart 1804'teki raporu konsolosun Sinop'tan beklentilerini oldukça iyi özetlemektedir: ${ }^{56}$

Sinop Karadeniz'in merkezinde yer almaktadır, limanı mükemmeldir. Burada gemileri daha ucuza ve daha kısa sürede kalafatlamak ve onarmak çok kolaydır, Mallar kolayca gemiye yüklenip boşaltılabilir. Ünye, Samsun ve Trabzon bu avantaja sahip değildir. Bunlar kötü limanlardır. Sinopluların karakteri olan iyilikleri, bunu başka yerde göremeyen tüccarlar ve gemiciler için bir güvenlik garantisidir. Diğer yerlerde ve özellikle de Trabzon limanında malların yüklenmesi çok zor ve pahalıdır. Bu son yer Erzurum'a Sinop'tan daha yakındır; fakat Tokat'ta da Trabzon'daki gibi iyi piyasası olan ve Erzurum'dan gelen mallara sahip olunabilir. Tokat'tan Kastamonu'ya malların nakliyesi kolaydır. Kastamonu'dan Sinop'a karayolu ile nakledilmeleri de Sinop ile Trabzon arasındaki navlundan daha yüksek değildir. Trabzon yolu malların bozulması, yüklenmelerindeki uzun süre ve diğer başka uygunsuzluklar sunmaktadır. Sinop'un ise bu durumda tercihi hak ettiği görülmektedir.

Fourcade bu olumlu tabloya karşın Anadolu'daki karışık ortamın da sergileyeceği olası tehlikelerin de hesaba katılması gerektiğini belirtmektedir. ${ }^{57}$ Zira iç kısımlarda küçük derebeylerin neden olduğu sıkıntılardan dolayı biraz endişelenmek gerektiğini; fakat Çapanoğlu ve Tayyar Mahmud Paşa kervanları koruduğunu ve Fransız tüccarlarının onların dostluklarını kazanmaları gerektiğini yazar. Sinop şehrinin bu sınırlı üretim ve tüketim koşullarında en önemli pazar olarak Kastamonu işaret edilmekte ve Sinop'un Kastamonu ile olan bağlantısı Sinop için bir kazanç olduğu ifade edilmekteydi. Hatta Fourcade Kastamonu'da, Fransa'nın, iç kısımlar ve İran'a kadar uzanan bir bölgede satacağı mallar için bir antrepo yapabileceğini; bir iki sene içinde Kastamonu'ya da ihtiyaç kalmayacağını ve kervanların mallarını alıp satmak için doğrudan Sinop'a geleceğini tasarlamaktayd1. ${ }^{58}$ 
Fourcade Fransız tüccarlarının Sinop ve çevre piyasalara yayılması için izlemeleri gereken yolu da belirliyordu. Buna göre tüccarlar acele etmeden Sinop ve Kastamonu piyasalarını doldurmadan deneme mahiyetinde alım satım yapmalı; fakat mal çeşitliliği İzmir ve Halep’teki gibi olmalıydı. Dahası Sinop'a kaptanları ve birkaç küçük gemi yerleşecek olan Fransız tüccarlar, Ereğli'den Trabzon'a kadar olan sahil ile Taganrok, Anapa, Kalas ve İstanbul ile ticaret yaparak kârlarını arttırabilirdi. Foucade, Fransız tüccarların ihtiyaç duyacağı bir antrepo, malların nakliyesindeki navlunlar hakkında da değerlendirmeler yaparak Fransızların ticareti için bir yol haritası belirtmekte ve Sinop limanının önemi göstermesi açısından 1804'ün ilk üç ayında limana sığına gemilerin bir listesini de raporuna eklemiştir. ${ }^{59}$ Fourcade avantajlarını göstermek için Sinop limanını sadece Güney Karadeniz'deki limanlar ile değil kuzeyde yer alan Odesa gibi önemli limanlar ile de mukayese ediyordu. Rusya'nın çok sıkı bir denetim yaptığı Odesa limanı özellikle Ocak ayındaki buzlanmadan dolayı emin bir liman değilken; halkının Fransızlara dost olduğu, gemilerin ihtiyaçlarının kolayca karşılanabileceği ve sıcaklığın da nadiren sıfır derecenin altına indiği Sinop, daha makul bir ticaret mahalli olarak gösteriliyordu. ${ }^{60}$

Bu yüksek beklentilerle görevine başlayan Fourcade'ın en önemli çabalarından biri de Sinop'ın dışına çıkarak seyahat edeceği bölgelerin üretim, tüketim ve ticaret potansiyellerini belirlemekti. Bu bakımdan konsolosluğuna başlar başlamaz Sinop dışına çıkmak için uygun bir firsat kollamıştı. İlerde daha ayrıntılı bir şekilde görüleceği gibi özellikle Kastamonu, Amasya, Ladik, Vezirköprü, Bafra, Çarşamba, Kavak ve Samsun bölgesinde gerçekleştirdiği gezilerde ayrıntılı bir şekilde buraların ticari potansiyeli üzerinde durmuş ve ayrıntılı raporlar hazırlamıştı. Çünkü bu bölgelerden iç kısımlarda yer alanlar için Sinop hem bir çıkış hem de Fransızların mal alıp satacağı pazar olarak görülmekteydi. ${ }^{61}$ Hatta konsolos 1807 yılında Trabzon ve Sohum taraflarına da bir seyahat planlamaktaydı; fakat Anadolu'daki karışıklıkların Fourcade'ı bu seyahatten alıkoyduğu anlaşılmaktadır. ${ }^{62}$ Buna karşın Sinop'un konsolosun bu yüksek beklentilerine karşllık verdiğini söylemek zordur. Zira konsolosun tüm planlarının odağında yer alan Tayyar Mahmud Paşa'nın 1805'de Yusuf Paşa karşısında yenilerek Sohum'a kaçması ve arkasından Kuzey Anadolu'ya hâkim olan kargaşa ortamı ve Osmanlı-Fransız ilişkilerindeki zaman zaman yükselen ortam nedeniyle Fourcade, Fransız ticaretini geliştirme konusunda tavsiyelerden öte bir faaliyet gerçekleştiremedi. Buna ilaveten Fourcade Anadolu'ya hâkim olan İngiliz ve Rus malları karşısında Fransızların çok şanslı olmadığını da görüyordu. ${ }^{63}$ Özellikle konsolosluğunun son dönemlerinde İngilizlerin Anadolu'daki yayılmalarına daha da sık değinmeye başlar. Buna göre İngilizler Anadolu'daki kargaşa ortamını değerlendirerek piyasaya yayılmakta, Anadolu'nun iç kısımlarında Erzurum'a; hatta Gürcistan, Abhaz sahilleri ve Kırım'a kadar ulaşmakta; Anadolu'ya ise bilhassa yünlüler, muslinler, şeker, kırmızböceği ve çivit ihraç etmekteydiler. ${ }^{64}$ İngilizlerin bu ilerlemeleri karşısında Fourcade'ın değerlendirmeleri Fransız ticareti açısından iç açıcı değildir. Fourcade her ne kadar Fransız ticaretinin gelişmesi için Anadolu halkının tercihlerinin bilinmesi ve buna uygun olarak buraya gönderilecek görevliler ile Anadolu pazarının tanınmasını tavsiye etse de ${ }^{65}$ özellikle de Tilsit Antlaşması ile Fransa'nın Ruslarla ittifak yapması Fransızlara karşı Anadolu'da bir kin ortaya çıard $1{ }^{66}$ Hatta bu kin ortamı Fourcade'ın konsolosluğunun kısa sürmesinde ve Sinop'u terk etmesinde de oldukça etkili oldu. Nihayetinde Fourcade'ın ikinci bir İskenderiye olarak gördüğü Sinop ne bir Fransız tüccarına ne de bir ticari antrepoya tanık olmaz; hatta hem Tayyar Mahmud Paşa 
sonrası kargaşa hem de 1806 Osmanlı-Rus Savaşı bölge ticaretine önemli bir darbe vurmuştur.

\section{Mitridat'ın Varisi: Tayyar Mahmud Paşa ile İlişkiler}

21 Bilindiği gibi Fourcade'ın konsolosluk döneminde, Kuzey Anadolu'daki en etkin idareci olarak, 18. Yüzyılın ikinci yarısından itibaren Orta Karadeniz'de etkili olan bir ayan ailesi olan, Caniklizâdelerden Tayyar Mahmud Paşa karşımıza çıkmaktadır. Tayyar Mahmud Paşa, babası Battal Hüseyin Paşa ile dokuz yıllık bir Rusya esaretinde kalmıştı. II. Katerina, Battal Hüseyin Paşa'ya Kırım'da zengin topraklar tahsis etmiş; Tayyar Mahmud Paşa ise bu sürede Rusya'da iyi bir askeri eğitim almıştı. Hatta Kırım'da Battal Paşa'ya tahsis edilen bu topraklar paşanın Anadolu'ya dönmesinden sonra da yine bu ailenin elinde kald $1{ }^{67}$ Fourcade'ın da belirttiği gibi, Tayyar Paşa Kırım'dan yıllık olarak çok yüksek bir gelir elde ediyordu. Battal Hüseyin Paşa 1799'da Anadolu'ya döndü ve Trabzon valiliğine getirildi. Fakat iki yıl sonra, 1801'de vefat edince Canikli ailesinin en etkili üyesi olarak geriye Tayyar Mahmud Paşa kaldı. 1801 yılında Anadolu'ya gelen Tayyar Mahmud Paşa'ya Samsun-Canik valiliği, Amasya, Merzifon ve Sinop'un muhasıllığı görevine getirildi. Bunun yanında isyan halinde olan Gürcü Osman Paşa'yı etkisiz hale getirmek için gerekli olan mali kaynakları elde edebilmek amacıyla Erzurum ve Diyarbakır valisi olarak atand1. ${ }^{68}$ Fakat Sultan III. Selim bu görevini başarı ile yerine getiren Tayyar Paşa'yı ödüllendirmek yerine idaresi altındaki toprakları ve unvanları elinden alarak Tayyar Paşa'nın hâkimiyet alanını Karadeniz kıyıları ile sinırlandırdı. Zira Tayyar Paşa 1803 yılında Sivas valiliğini devletten talep etmişti. Fakat III. Selim Tayyar Paşa'nın Rusya ile olan ilişkileri nedeniyle Anadolu'nun iç kısımlarında bu görevi ona vermek istemedi. Bunda Çapanoğlu ailesinin Caniklizadeler aleyhine hükümet nezdindeki girişimleri de etkili olmuştu. Bunun yanında Çapanoğulları da topraklarını Caniklizadeler aleyhine genişletmek istiyordu. ${ }^{69}$ Böylece Anadolu'da Caniklizadeler ile Çapanoğulları arasında var olan çatışma ortamı yeni bir boyut kazandı. İşte 1803 yılından itibaren başlayan bu çatışma ortamında görevine başlayan Fourcade'in en önemli gayesi de konsolosluk bölgesinde en büyük güç olan Tayyar Paşa'nın himayesini kazanmak ve onunla iyi ilişkiler tesis etmekti.

Fourcade, konsolosluğunun 1805 yılına kadar olan döneminde en büyük gaye olarak Tayyar Mahmud Paşa'nın güvenini kazanarak, onu, hâkimiyeti altındaki bölgeler ile Fransa arasında yapılacak doğrudan bir ticarete ikna etmek olduğunu ifade etmektedir. Tayyar Paşa'nın Anadolu'daki iktidarı, Rusya ile olan ilişkileri ve Çapanoğlu ile olan mücadelesi Fourcade'ın en bu ilk dönemde en çok değindiği konulardı. Zira Tayyar Mahmud Paşa Fourcade'ın tüm planlarının merkezinde yer alıyordu. Ona göre küçük ağalık rejimi ticarete uygun değildi ve iş yapacak tek bir liderin olması daha iyiydi. Kendi deyimiyle bu durumu "kendi çıkarlarına göre gümrüğe sahip olmak, alım ve satımı kendine göre yapmak isteyen otuz tiranın arasında ne yapılabilirdi" ${ }^{70}$ ve "Eğer bu paşanın dostluğunu kazanabilirsek bizim buradaki ticari ilişkilerimiz daha kolay kurulabilir. İmparatorluğun tüm eyaletlerini yakıp yıkan tiranlığa susamış ve birbirine karşı sürekli olarak mücadele eden bağımsız küçük senyörleri ve lordları denetimi altında tutan güçlü bir kişi ile ilişki kurmak çok iyi olacaktır" gibi ifadeler ile dile getiriyordu. ${ }^{71}$ 

kuşkulandığı husus Tayyar Paşa'nın Ruslar ile olan ilişkileridir. Zira Fourcade, Tayyar Paşa'nın, kendisine Kırım'da arazi tahsis eden Rusları koruduğuna dair kuşkular barındırıyordu..$^{72}$ Bizzat Tayyar Paşa da kendisine yöneltilen bu suçlamaları ortadan kaldırmak için mücadele de ediyordu. Fourcade, Tayyar Paşa'nın Rusların işine gelmeyecek derecede padişaha bağlı olduğunu; Osmanlı hükümetinin de Anadolu'daki isyancıları bertaraf etmek için onun gücüne muhtaç olduğunu belirtmektedir. Fakat Tayyar Paşa'nın Rusya ile olan ilişkisi nedeniyle Osmanlı hükümetinin topraklarını genişletmesine müsaade etmediğini de ifade etmektedir. ${ }^{73}$ Gerçekten de Fourcade'ın belirttiği gibi Tayyar Paşa'nın Anadolu'da geniş bir hâkimiyet kurmak gibi planları vardı. Bun konuda Fourcade, Tayyar Paşa'yı en büyük rakibi olan Çapanoğlu Süleyman Bey ile mukayese ederek bazı değerlendirmeler yapar: ${ }^{74}$

Tayyar Paşa Erzurum'dan Kastamonu'ya kadar ve Karadeniz'in güneyinden Çapanoğlu'nun bölgesine kadar olan bölgenin hâkimidir. Çapanoğlu, Tayyar Mahmud'un düşmanıdır. Çapanoğlu daha mutedildir, zevki ve dinginliği sever. Tayyar Mahmud Paşa ise tedirgin, cesur, kendine güvenen ve bu son avantajlarıyla gurur duyan biridir. Özellikle de muzaffer bir ordu ile gurur duymaktadır. Eğer bir Cezzar veya bir Pazvandoğlu olmak isterse Bâb-1 Âli onu engelleyecek güçten yoksundur. Açık bir şekilde görüyorum ki Tayyar Mahmud Paşa bütün kuzey Anadolu'nun hâkimi olmayı amaçlamaktadır. Tayyar Paşa, eğer bilinmeyen bazı durumlar onun tutarlılığını yavaşlatır ve üzerinden gelinemeyen engeller ona karşı çıkmazsa Mitridat'ın tüm mirasını elde edecektir.

Fourcade, Rus konsolosu Konuchenco ile Tayyar Mahmud Paşa'nın Anadolu'daki durumu hakkında yaptığı müzakerelerde Anadolu'daki gelişmelere Rusların yaklaşımını da ortaya koymaktadır. Rus Konsolosu Konuchenco, Rusların Anadolu'da Erzurum'dan İzmit'e kadar hâkimiyet kurmak isteyen Tayyar Paşayı desteklemeyeceğini; aksine, bir şekilde, Osmanlı hükümetinin Tayyar Paşa'nın bu planlarını engelleyeceğine inandığını ifade ediyordu. Bu şekilde Rus meslektaşının ifadelerini aktaran Fourcade, Anadolu'da Fransız çıkarları için Rus yanlısı olmayan ve huzuru sağlayacak birinin bölgede etkin olmasını istiyordu. Zira Rusların olası bir Anadolu hâkimiyeti Fransızları bütün planlarından vazgeçirecek ve onları "barbarlıkta Türklerden aşağı kalmayan yeni bir efendi” ile karşı karşıya bırakacaktı. Bu bakımdan Fourcade, politik ve askeri faziletlerine methiyeler yağdırdığı Tayyar Mahmud Paşa'nın varlığını kendi çıkarları için en önemli dayanak olarak görür. ${ }^{75}$ Konsolosa göre Tayyar'ın iktidardan düşmesi tüm planlarının sonu ve Anadolu'da yeni bir anarşi ortamı demekti. Bu konuda yol haritası olarak şunları belirler: "Sivil savaşların pençesinde olan bir bölgede tüccarlar ne yapabilir? O zaman Tayyarı kaybedebilir miyiz? Hayır, Asya'da (Anadolu) ticareti yerleştirerek oraya bir adım atıp, burada bir bölgeye sahip olup Rusların etkisini dengeleyebilir miyiz? Evet. O halde şartlardan istifade ederek onlardan lehimize sonuçlar çıkarmalıyız. Tayyar Paşa'nın dostluğunu fethetmemiz gerekir". ${ }^{76}$

Fourcade bu planları gerçekleştirmek için epey bir süre Sinop'ta beklemek zorunda kaldı. Hatta yukarıda vermiş olduğumuz değerlendirmeler Fourcade'ın Tayyar Paşa ile görüşmeden önce Sinop'taki Rus konsolosundan ve diğer bilgi kaynaklarından hareketle yaptığı değerlendirmelerdi. Fourcade Tayyar Paşa ile iyi ilişkiler için zemin oluşturmanın yanında Sinop'un ticareti konusunda başka bazı girişimleri oldu. Hatta Çapanoğlu ile de haberleşerek kontrolü altındaki bölgeler ile ticaret yapılması yönünde 
hamlelerde de bulundu. ${ }^{77}$ Tayyar Paşa'nın Sinop'taki kâhyası ile iyi ilişkiler kurarak Tokat, Amasya, Ankara ve Anadolu'nun tüm önemli pazarlarından gelerek İzmir'e giden tüm tüccarların Sinop'ta ağırlanabileceğine dair teminat almıştı. ${ }^{78}$ Fakat 1804'ün Mayıs'ında Bafra'ya gerçekleştirdiği bir seyahat ile Tayyar Paşa ile daha yakından bağlantı kurma fırsatını yakaladı. Bafra'da Tayyar Paşa'nın kâhyası tarafından oldukça iyi bir şekilde karşılandı. Kâhya, bölgede yetişen ürünler, fiyatları ve takas vasıtaları gibi konularda Fourcade'a önemli bilgiler aktardı. Fourcade bu ilk olumlu temastan sonra Sinop'a döndü. Ağustos 1804'te Bafra'ya gelen Tayyar Paşa, Fourcade'a mektup göndererek onu görüşmek üzere Bafra'ya davet etti; hatta konsolosla bir görevli ve bir koruma da tahsis etti. ${ }^{79}$ Tekrar Bafra'ya gelen Fourcade uzun zamandır planlarını yaptığı gibi 1 Fructidor An 12/19 Ağustos 1804'te Tayyar Paşa'nın huzuruna çıkt. ${ }^{80}$ Tayyar Paşa, Fourcade'ı sıcak bir şekilde karşıladı. Kendi idaresi altında ticari görevliler bulundurmak ve onlara gerekli kolaylıkları sağlamak konusunda Fourcade'a teminat verdi. Fourcade'ı asıl etkileyen ise Tayyar Paşa'nın, Napolyon, Elçi Brune ve Fransızlara gösterdiği iltifat oldu. Fourcade, Tayyar Paşa'nın bu sıcak karşılamasından oldukça etkilenmiş olacak ki kendi tarafından talep edilmeden, Tayyar Paşa'nın savaşın sona ermesi durumunda, Samsun Trabzon ve Sinop'ta yerleşmek isteyen tüccarlara mağaza ve ev vereceğini söylemesi konsolosu çok şaşırtır. Hatta Tayyar Paşa, bu görüşmelerde Kızılırmak ağzında, Kumcağız'da bir liman inşa etme planlarından da bahsetmekteydi. ${ }^{81}$ Fourcade ile Tayyar Paşa arasında 2 Fructidor'da ikinci ve daha uzun bir görüşme gerçekleşti. Fourcade bu görüşmelerde, Tayyar Paşa'nın Anadolu'nun iç kısımları ve özellikle de kendi kontrolünde olan bölgeler ile Fransa arasında kurulacak ticari ilişkilerin getirilerini anladığını belirtmektedir. Buna karşın Tayyar Paşa'nın bazı yersiz kaygılarının olduğunu ekler. Bu bakımdan konsolos, gerek Bâb-1 Âli nezdinde İstanbul'da gerekse de yerel idareciler nezdinde Karadeniz'deki limanlarda ticari ilişkiler dışında bir maksatlarının olmadığını göstermeye çalıştı̆̆ını da ifade ediyordu. $\mathrm{Bu}$ konuda Tayyar Paşa, Fourcade'ın Sinop'taki varlı̆̆ından memnun olsa da, Trabzon'da Dupré'nin Rum ve Ermeniler için himaye talep etmesinden de rahatsız olmaktayd.$^{82}$

$\mathrm{Bu}$ olumlu görüşmelerden sonra Fourcade Tayyar Paşa'yı memnun etmek için elçilik aracılı̆̆ıyla bazı hamlelerde bulundu. Bu hamle Tayyar Paşa'nın kontrolünde olan Trabzon gümrüğü hakkındaydı. Fourcade, General Brune'dan Tayyar Paşa'nın "himayesini kazanmak ve aralarındaki barış ortamını muhafaza etmek" için İstanbul'daki gümrük ödemeleri ve Fransızların Sinop, Samsun ve Trabzon'a Fransız ve Rus gemileriyle gönderdikleri malların bu limanlarda gümrüğe girmeleri konusunda aracı olmasını talep ediyordu. ${ }^{83}$ Konsolosun bir diğer hamlesi de Tayyar Paşa'nın hizmetinde olan Venedikli Doktor Bozari'nin aracilığına başvurmaktı. Fourcade, Bozari'den Trabzon gümrüğünde karşılaşılan sorunlar, Sinop'taki Rumların kâhyası ve şehrin kadısının görevine devam etmesi gibi konularda aracilık yapması istedi ve bu isteklerinin tümünü elde etti. Bozari'nin Tayyar Paşa nezdindeki girişimleri Sinop'ta Fransızlar için çok iyi bir ortam oluşturdu. Bu bakımdan Fourcade, Tayyar Mahmud Paşa üzerinde etkili olan Bozari'nin aracıllğını "gerçek bir mutluluk kaynağı" olarak belirtmekteydi..$^{84}$

Fourcade ile Tayyar Paşa arasında ticari ilişkiler konusundaki mutabakat çok geçmeden bazı ciddi engeller ile karşılaştı. Aslında bizzat Tayyar Paşa da özellikle Rusya'nın, Fransızların Anadolu'daki varlığından rahatsız olduğunu biliyordu. Fourcade, Odesa, 
Taganrog ve Kefe'yi iyi tanıyan Tayyar Paşa'nın Trabzon, Samsun ve Sinop limanlarının kuzeydeki bu limanlara göre daha avantajlı olduğunu bilmekle birlikte Marsilya ile kendi bölgesi arasında kurulacak doğrudan bir bağlantının Rusları rahatsız edeceğinin de farkında olduğunu belirtmekteydi. Hatta bu konuda hazırlıklar yapılmış ve gemiler de tedarik edilmişti. Fakat Rus konsolosunun araya girmesi ile birlikte Tayyar Paşa bu plandan vazgeçti. Fourcade'a göre Tayyar Paşa'ya her yıl Kırım'daki toprakları için 20,000 kuruş veren Ruslar, onun Fransızlar ile olan bu ilişkilerine engel olmak istiyordu. ${ }^{85}$ Ruslar, Anadolu'daki Fransız konsolosluk ağını da, Türklerin Ruslara karşı nefret ve kinlerini besleyen, onları Ruslara karşı savaşa teşvik eden ve Kırım'ın ticaretine zarar veren kurumlar olarak görüyordu.$^{86}$ Üstelik Rusların bu kıskançlığının, Anadolu ile çok az ticari ilişki içinde olmaları hasebiyle ticari bir kaygıdan ziyade politik nedenlere dayandığını ve Rusların Güney Karadeniz şehirlerinden kendi ülkelerine nüfus naklederek oraları müreffeh yapma amacında olduklarını da görmekteydi. ${ }^{87}$

Fourcade'ın Tayyar Paşa ile ilişkileri sayesinde Sinop'ta oluştuğunu gördüğümüz ve konsolosun da özellikle dile getirdiği bu Fransız yanlısı hava gerek Rus konsolosunun aksi politikaları gerekse de Tayyar Paşa'nın Anadolu'da sarsılan iktidarı nedeniyle çok uzun sürmedi. Bu karışı ortam Fourcade'ın raporlarında dile getirdiği en kaygı verici durumdu. Daha 1804'ün Mart'ında “Bir vali değiş̧ikli değişikliği olmasını görmen benim şanssızlığım olacak" 88 diyen Fourcade ayını yılın sonlarına doğru Tayyar Paşa'nin idaresinin çok uzun sürmeyeceğini anlamaya başlamıştı. Anadolu'da Tayyar Paşa'nın genişleyen hâkimiyet alanı aynı zamanda muhalif bir kesim de yaratıyordu. Fakat daha da ilginci Tayyar Paşa'nın İstanbul'da kendisine karşı bir grubun oluştuğuna inanmasıydı. Bundan dolayı Fourcade Anadolu'da Tayyar Paşa'nın olası bir düşüşünün Bâb-1 Âli'nin değil aksine Rusya'nın işine gelecek bir durum olduğunu ve böyle bir durumun Anadolu'ya "haydutluk ve eşkıyalı̆̆" yeniden getireceğinden korkuyordu. ${ }^{89}$

Fakat Forurcade'in değinmediği ve Bâb-1 Âli'yi tedirgin eden en önemli gelişme ise Tayyar Paşa'nın Nizam-ı Cedid'e karşı Anadolu'da yürüttüğü aksi kampanyaydı. Belki bunda Tayyar Paşa'nın en büyük rakipleri olan Çapanoğullarının, Nizam-ı Cedid'e aktif destek vererek karşllı̆ıında, geleneksel olarak Caniklilerin kontrolünde olan Amasya'yı almalarının da etkisi vardı. Bunu bir türlü kabul etmeyen Tayyar Paşa 1805 yılının Ocak ayında Sinop' $\mathbf{u}^{90}$ kendisine merkez tayin ederek topladığı yaklaşık elli bin adamıyla harekete geçerek Amasya'yı ele geçirdi. Anadolu'da yeni bir çatışmayı önlemek isteyen ve Bâb-ı Âli Amasya'yı Çapanoğullarından geri aldı; ancak buranın idaresini ne Çapanoğullarına ne de Tayyar Paşa'ya verdi. ${ }^{91}$ İstediklerini elde edemeyen Tayyar Paşa ise kendisine gönderilen nasihat fermanlarını dikkate almayarak Amasya'yı tekrar ele geçirerek Tokat, Zile, Sivas ve Çorum taraflarına doğru harekete geçti. Bunun üzerine Bâb-1 Âli, Tayyar Paşa'nın Rusya ile bağlantılı olduğu düşünerek onu asi olarak ilan etti ve tüm yetki ve sorumlulukları askıya aldı. Daha evvel Trabzon valiliği yapmış olan Yusuf Ziya Paşa, Trabzon ve Erzurum valisi olarak tayin edilerek Tayyar Paşa'yı ele geçirmekle görevlendirildi. ${ }^{92}$ Tayyar Paşa'nın adamlarının Çapanoğlu ve Yusuf Ziya Paşa tarafından yenilmeleri üzerine Tayyar Paşa Temmuz 1805'te hükümetten affını istedi ve Nizâm-ı Cedîd'e asker toplayacağına söz verdi. Osmanlı hükümeti Tayyar Paşa'nın bu talebini kabul etmedi ve nihayetinde Yusuf Ziya Paşa'nın kuvvetlerince yenilen Tayyar Paşa Sohum kalesine kaçtı ve oradan da Kırım'a sığındı. ${ }^{93}$ Bunun yanında Yusuf Paşa'nın Tayyar Paşa'yı etkisiz hale getirmesinde Fourcade'ın da 
belirttiği gibi Yusuf Paşa'nın bazı entrikaları da etkili olmuştu. Fourcade, Tayyar Paşa'nın yenilerek Sohum'a kaçışı üzerine aşağıdaki değerlendirmeleri yapıyordu: ${ }^{94}$

Yusuf Paşa'nın sözlerine bir çocuk gibi kanan ve savaşmadan yenilen Tayyar bir asi olarak yaşamayı bilmediği için yasaklı biri olarak ölecektir. ilke olarak, zayıf hâkimiyetine muhalif olan ve satın almadığı vezirler ve nefret ettiği yabancılar tarafından sevilmeyen Tayyar, ya ortadan kalkmalı ya da bir ihtilal yapmalıydı. Fakat başarılarına, insanların sevgisine ve gururu kanan Tayyar, bir güç olarak görülmeye başlandı. Az kalsın kendi küçük imparatorluğunun temellerini atıyordu. Bâb-1 Âli'nin kendisine bir Cezzar veya Pazvandoğlu gibi davrandığını düşünüyordu. Fakat onun şartları ve ünü farklıydı. Ayrıca o bu kişiler gibi, sarayın desteğiyle kan ve tere susamış biri değildi...

Tayyar Mahmud Paşa'nın düşüşünden sonra Anadolu tam bir kargaşa ortamına girdi. Her ne kadar Tayyar Paşa'nın iktidarı sona erse de geride kalan taraftarları ile Yusuf Paşa arasındaki çatışmalar uzun bir süre bölgedeki anarşi ortamını devam ettirdi. ${ }^{95}$ Fourcade'a göre bu gelişmeler Tayyar Paşa'nın “Anadolu'nun hâkimi” olmasını istemeyen Rusların "zevkle” izlediği gelişmelerdi. Fourcade'ın bu dönemki diğer yazışmaları Tayyar Paşa'nın destekçilerine karşı yürütülen kampanyayı ortaya koyduğu kadar ilerde bir başka etkili bir vali sülalesinin temelini atacak olan Hazinedaroğlu Süleyman Ağa'nın da ilk dönemlerini aydınlatmaktadır. Bu anarşi ortamı hakkında Fourcade, Tayyar Paşa'nın valiliğinde bir çocuğun endişe etmeden Sinop'tan Trabzon'a gidebilirken Tayyar Paşa sonrasında Sinop'tan Kızılırmak'a kadar öldürülme riski olmadan seyahat edemeyeceğini ifade ediyordu. ${ }^{96}$ Konsolosa göre Yusuf Paşa'nın birlikleri tüm Canik'te yıkımlar yapmakta ve yörenin ileri gelen zengin kimselerinin hapse atmaktaydı. Fourcade, Bâb-1 Âli'nin bu duruma müdahale etmemesi durumunda Karadeniz sahilinde yıkımın büyük olacağını; Tayyar Paşa'nın düşüşünden itibaren, zulüm ve suçların bir zamanlar Tayyar Paşa'nın yönettiği yerleri mesken haline getirdiğini ve bundan dolayı Türk, Tatar, Rum ve Ermenilerin Kırım'a kaçtıklarını yazıyordu. ${ }^{97}$

Fourcade'ın raporlarında Tayyar Paşa'nın Sohum'a sığınmasından sonraki gelişmeler hakkında da bilgiler yer almaktadır. Burada özellikle dikkat çeken husus, Yusuf Paşa'nın Memiş Efendi adında biriyle Tayyar Paşa'yı zehirleme girişimiydi. ${ }^{98}$ Belki de daha da ilginci ise Fourcade'ın Tayyar Paşa ile haberleşmesiydi. Tayyar Paşa, kendisini Sohum'da himaye eden ve kendisine verilecek ceza konusunda Bâb-1 Âli ile anlaşmazlığa düşen Sohum Muhafızı Keleş Bey ${ }^{99}$ vasıtasıyla Fransız imparatoruna mektup göndererek Fransa'nın korumasını talep ediyordu. ${ }^{100}$ Fakat bu girişimden bir netice almadan Tayyar Paşa Kırım'a sığınmak zorunda kaldı. Bu şekilde Fourcade tüm planlarını dayandırdı̆̆ı Tayyar Paşa'nın düşüşüne şahit oldu. Gerçekten de Tayyar Paşa'nın iktidarının sarsılmaya başladığı dönemden itibaren, Fourcade olası bir vali değişikliğinin nasıl sonuçlar doğuracağını kestirmişti. Bundan dolayı en büyük arzusu Tayyar Paşa'nın iktidarının devam etmesiydi. Fakat Fourcade, Tayyar Paşa ile tesis etmeye çalıştığı ilişkilerin sonucunda hiçbir şey elde edemediğini şu sözlerle ifade etmekteydi: ${ }^{101}$

Tayyar Paşa'nın bizim ticaret gemilerimiz gelmeden Fransa ile ticari ilişkiler kurma konusundaki projelerini unutmayacağım. Bana Fransız malları için komisyon vermişti. Onun niyeti tüm çevresini Fransız yünlüleri ile giydirmekti. Bana bir Katolik kilisesi için yer tahsis etmişti. Trabzon, Samsun ve Sinop'a gelip yerleşmek isteyen tüccarlar için mağaza yaptırtmak istiyordu. Mareşal Brune'un ayrılması onun bu planlarını gerçekleştirmek için tek engeldi. Biz temelleri daha önce 
atmalıydık. Tayyar Paşa'nın, Trabzon'da Dupré’ye yaptığını unutmayacağım. Sinop'taki 22 aylık ikametim sırasında bir şikâyet konusu olacak bir şey oluşturmadım. Tayyar Paşanın adamları her zaman benim istek ve ihtiyaçlarımı engelledi, iki yüzyıldan beri bu iskeleler ile irtibat halindeyiz. Buna benzer bir hadise ve aynısı gibi bir örneği bulabileceğimizi zannetmiyorum.

\section{Sinop'ta Güçlü Bir Rakip: Rus Konsolosu Konuchenco Faktörü}

Bilindiği gibi 1768 yılında başlayan Osmanlı-Rus savaşı sonrasında imzalanan Küçük Kaynarca Antlaşması (1774) Karadeniz'in tarihi açısından da önemli bir dönüm noktasıdır. Özellikle antlaşmanın 11. Maddesi Karadeniz'in ticari statüsünde önemli bir değişiklik öngörüyordu. Bu maddeye göre Rusya ticaret gemileri Akdeniz'den Karadeniz'e ve Karadeniz'den Akdeniz'e geçebilecek; kıyılar, sahiller, limanlar ve boğazlardan ticaret amacı ile yaralanabilecek; Rus tüccarlarına İngiltere ve Fransa tüccarı gibi davranılacak ve tüccarlar karalarda ve Tuna nehrinde serbestçe ticaret yapabilecek ve daha da önemlisi Rusya, Osmanlı Devleti sınırları içerisinde istediği yerlere konsolos ve konsolos vekilleri tayin edebilecekti. ${ }^{102} \mathrm{Bu}$ madde ile Rusya, Fransa ve İngiltere'nin yüzyıllardır elde etmek için mücadele ettikleri bir hakkı elde etmiş oldu. Konsolosluk kurma hakkına istinaden Rusya, etkilerini ilerleyen dönemde özellikle sosyal ve ekonomik hayatta görülen dengesizliklerin, huzursuzlukların ve entrikaların bir açıdan kaynaklarından biri olan Osmanlı İmparatorluğu'ndaki en yaygın konsolosluk ağını tesis etmeye başladı ${ }^{103}$ Rusların konsolosluk açmak için ilk tercih edilen yerler ise Selanik, İzmir, Kıbrıs, Rodos, Girid, Sakız, Sisam, Boğazhisarları, Trablusşam, Mora, İskenderiye, Sayda, Arnavutluk, Eğriboz Adası, Santeron, Nakşa, Eflak ve Boğdan oldu. Bu konsolosların en önemli görevi ise istihbarat faaliyetleri yürütmek ve reaya arasında karışıklık çıkarmaktı. ${ }^{104}$ Anlaşmanın hemen arkasından başlayan bu atama sürecinde 1785 yllında Sinop'a da bir konsolos tayin edildi. Bu ilk konsolosun Fourcade'ın Sinop'a geldiğinde şehirdeki Rus konsolosu Konuchenco mu olduğunu bilemiyoruz; ${ }^{105}$ fakat Köse, Sinop'taki bu ilk konsolosun hiç de iyi karşılanmadığını ve görevine başlar başlamaz Sinop’ta kendisine karşı oluşan hava nedeniyle can korkusuyla kendini İstanbul'a attığını belirtmektedir. Nitekim Rus konsolosu, Rus elçisi Boulgakofun kararlı politikaları sayesinde, kendisine karşı halkı kışkırtmakla suçlanan kadı ve müftünün görevden alınarak cezalandırıldığı Sinop'a, kendisiyle uğraşılmasının bedelinin ne olacağını gösterir bir şekilde yeniden döndü. ${ }^{106}$

Her ne kadar Konuchenco'nun şehirdeki ilk Rus konsolosu olduğu konusunda kesin verilere sahip olmasak da Rus konsoloslarının Sinop'ta bazı idareciler tarafından hiç hoş karşılanmadığı anlaşılmaktadır. Fourcade'ın yazışmalarından da anlaşıldığı gibi Fourcade, Sinop kadısı ile oldukça sıcak ilişkiler kurmuş; hatta Venedikli Doktor Bozari vasıtasıyla Sinop kadısının değiştirilmemesi için Tayyar Paşa nezdinde girişimde bulunmuştu. Bunun bir nedeni de kadının Rusları sevmemesiydi. Zira 28 Mart 1806 tarihli raporda Fourcade, kadı ile olan görüşmelerinde, kadının kendisini Rusların görevden aldığını belirtmesi bize şehre Rus konsolosunun atanması sürecinde yaşananları hatırlatmaktadır. ${ }^{107}$ Ayrıca kadı'nın Ruslara karşı olan kini, 1806'da patlak veren Osmanlı-Rus savaşı sırasında şehri terk etmek zorunda kalan Rus konsolosuna olan muamelede de görülecektir. şehirde Konuchenco'nun entrikalarına karşı koyan tek kişi kadıydı ve Rus konsolosunun, reayanın Rusya'ya göçe teşvikine engel olmaya 
çalışmaktaydı ${ }^{108} \mathrm{Bu}$ bakımdan kadı ile Konuchenco arasında bir husumet olduğu; fakat bu kez bu husumetten, Konuchenco'nun şehirden çıkarılmasıyla Kadı'nın galip geldiği görülmektedir. ${ }^{109}$

Yukarıda da değindiğimiz gibi Rusya kendi gölü olarak gördüğü Karadeniz'de diğer güçlü Avrupa devletlerinin yer almasını büyük bir kıskançlıkla izliyordu. Bu siyasetin sahibi Rusya'nın Sinop'taki temsilcisi olan Konuchenco da Fourcade'ın konsolosluğunun başarısız olması için elinden gelen tüm gayretleri göstermiştir. Hatta Fourcade ilk raporlarında karşısındaki en büyük engeller olarak Avrupalı Hıristiyanlarla iş yapmaya alışkın olmayan Asyalıların önyargıları ve Rusların kıskançlığını sayıyordu. Gerçekten de Rus konsolosunun şehri terk ettiği 1807 yılının başına kadar Sinop’ta adeta “diplomatik bir savaş” cereyan edecekti. Her iki konsolos da birbirini sıkı sıkı takip edecek ve birbirlerine engel olmaya çalışacaklardı. Aslında Konuchenco'nun şehirdeki yeni meslektaşına karşı olan tavırları çok geçmeden Fourcade'ın dikkatini çekmeye başlamıştı. Fourcade Sinop'a gelir gelmez Tayyar Paşa ile görüşmek istemiş ama Rus konsolosu bu görüşmeye engel olmaya çalışmıştır. Konuchenco, Fourcade'a çok farklı bir Tayyar Paşa profili sunarak onu asla ziyaret etmemesini tavsiye ediyor ve Sinop'u terk etmemesi durumunda öldürüleceğine dair dedikoduların olduğu gibi caydırıcı telkinlerde de bulunuyordu. Rus büyükelçisinin, Karadeniz'e açılmak isteyen Fransız gemilerini engellemeye çalışması gibi Konuchenco da Dupré'yi Trabzon'a getiren gemiyi engellemek için elinde geleni yapmıştı. ${ }^{110}$ Fourcade, Konuchenco'nun bu tavırlarını elçilikten aldığı talimatlara göre yaptığını belirtiyordu. Fourcade, Rus meslektaşı ile olan ilk karşılaşmaları ve aralarındaki mektuplaşmalar hakkında Ekim 1804'te Fransız Dışişlerine 27 sayfalık uzun bir rapor “mémoire" hazırladı. ${ }^{111}$ Aslında Fourcade'ın, Konuchenco'nun Sinop'taki tecrübesinden dolayı vereceği bilgilere ihtiyacı vardı. Ancak Konuchenco bu konuda çok anlayışlı olmamıştır. Fourcade bu uzun mémoire'ın sonunda Rus konsolosu hakkında şu değerlendirmeleri yapıyordu. ${ }^{112}$

Karadeniz kıyılarına Fransa ile Anadolu arasında ticari ilişkiler kurmak için gönderilen ben, Osmanlılar ile olan tüm ilişkilerimi iyi karşılanmayı hak edecek derecede bir barış görevlisi olarak ılımlı ve saygılı şekilde yürüttüm. Rus konsolosu ile dost bir ülkenin konsolosu ve ticari refahın bizim Karadeniz'de kurabileceğimiz müesseselere bağlı olduğunu bana gösterecek bir görevli gibi yaşamak isterdim. Ama Rus konsolosunun aynı fikirleri paylaşmadığını anlamam uzun sürmedi.

Fourcade, Rus konsolosunun Osmanlıları rahatsız etmek bir görevi olduğunu, halkı kendilerine karşı kışkırttığını ve Sinop'ta zor durumda kalmamak için burayı terk etmesi gerektiği gibi kendilerine onur kırıcı bir muamelede bulunduğundan şikâyet ediyordu. Fourcade, Konuchenco'yu kişilik olarak "dürüst bir adam"113 olarak nitelese de ülkesinin çıkarları söz konusu olduğunda şiddete varıncaya kadar her türlü vasıtayı kullanmayı ihmal etmediğini ve kendisini "düşman" olarak gördüğünü belirtmektedir. ${ }^{114}$ Konsolosa göre hükümetinden bu yönde talimat almayan bir görevlinin Sinop’ta bu davranışları sergilemeye cesareti olamazdı. Buradan hareketle Fourcade, görevleri için gerekli beratların elde edilmesi, Kırım'dan aldığı mektuplar, Trabzon paşasına (Tayyar Paşa) yapılan başvuruların kendilerine yeteri kadar fikir verdiğini ve Rusların "Karadeniz'in Anadolu sahilini kendilerine kapatmak" istediklerini anladığını yazarak bu uzun raporunu bitiriyordu. ${ }^{115}$ gösteriyor, Fourcade'a Sinop, Trabzon, Tokat ve Erzurum'da ticarete konu olabilecek 
bir mal olmadığını söyleyerek onun gerçekleştirmek istediği seyahatlerde karşılaşacağı zorlukları öne sürüyordu. Bunun yanında Fourcade, Rus meslektaşının Rusya'nın bu taraflarda hiçbir ticareti olmadığını söylemesine ve Bâb-ı Âli'nin yasaklamasına karşın Rus gemilerinin sık sık Sinop limanına girdiğini de gözlüyordu. ${ }^{116}$ Aslında Ruslar Anadolu ile çok yoğun bir ticari ilişki içinde değillerdi ve Amasya'dan çok az ipek alıyorlardı. Fakat bunun ötesinde politik bir plan çerçevesinde Ruslar, Güney Karadeniz şehirlerinden kendi ülkelerine nüfus çekmek amacındaydılar. ${ }^{117}$ Gerçekten de Tayyar Paşa sonrasında Anadolu'ya hâkim olan kargaşa sırasında Sinop'a sığınan 4,000'den fazla Müslim-gayrimüslim arasında, Rus konsolosu propaganda yaparak, onları Kırım'a gitmeleri için elinden geleni yapmıştı. Konuchenco, sığınmacıların içinde bulunduğu zor durumdan istifade ederek onlara Rus ordusunda istihdam edilme gibi vaatlerde bulunuyordu. ${ }^{118}$ Fourcade Sinop'taki durumu hakkında yaptığı değerlendirmelerde Sinop halkından çok Rus konsolosunun entrikalarından yakınmaktadır. Anadolu'nun Karadeniz sahillerindeki politik ve ticari durumu söz konusu olduğunda Rusların sürekli olarak Fransızların karşısında yer aldıklarını, her firsatta düşmanlıklarını gösterdiklerini ve şehirde karşılarına çıkan tüm kötülüklerin Rus konsolosunun etrafında döndüğünü belirtiyordu. ${ }^{119}$ Rus konsolosu özellikle şehirdeki Rumlar arasında büyük bir itibar sahibiydi. ${ }^{120}$ Rusların Rumları himaye etme çalışmalarıyla Rum Mahallesi sürekli bir karışıklık içindeydi. şehre gelen Rus gemilerinin tayfaları geceleri şehirde olaylar çıkarıyordu. ${ }^{121}$ Rus konsolosunun tutumunu göstermesi açısından konsolosluğun 1806 şubat'ında Rus bandırası taşıyan bir geminin mürettebatı tarafından uğradığı saldırı Fourcade için bir dönüm noktası olmuştur. ${ }^{122}$

Sinop'ta bu iki konsolos arasında yaşanan çekişmede Fourcade da Rus konsolosunun faaliyetlerini dikkatle takip ediyordu. Konsolosluğun ilk dönemlerinde Fourcade'ın Sinop dışına çıkarak yapmak istediği incelemelerde en büyük engel Konuchenco'nun entrikalarıydı. Bu bakımdan Rus konsolosunun Sinop'ta olmadığı dönemler Fourcade için tam bir özgürlük ortamı demekti. ${ }^{123}$ Rus konsolosunun Tayyar Paşa nezdinde önemli bir gücü vardı. Konuchenco Eylül 1803’te Tayyar Paşa ile görüşmek için Trabzon'a gitmişti. Fourcade bu sayede Konuchenco ile Tayyar Paşa arasında çok sıcak bir dostluğun oluştuğunu ve Tayyar Paşa'nın Sinop'taki görevlisi gibi hareket eden Rus konsolosunun istediği her şeyi elde edebildiğini belirtiyordu. ${ }^{124}$ Gerçekten de Fourcade'ın tüm yazışmaları Rus konsolosunun Sinop'taki iktidarını ortaya koymaktaydı. Tayyar Paşa'nın desteği ile Konuchenco, Fransız konsolosuna pek çok zorluk çıkardı. Konuchenco, Tayyar Paşa sonrası Yusuf Paşa'nın yakınlığını kazanmak için de bazı girişimlerde bulundu. Bu maksatla 1806 Ocak'ında Erzurum taraflarına bir seyahat gerçekleştirdi. Fourcade Rus konsolosunun bu seyahatine ilişkin tahminlerini şu şekilde elçiliğe iletiyordu: ${ }^{125}$

Birçok defa konsolosun Kastamonu ve Amasra taraflarına gitmesine izin çıkmadı. Sivil savaşlardan harabe haline gelen, dağlık ve yağışlı bir ülkede, yılın en kötü mevsiminde yapılacak olan bu yolculuğun Rus elçiliği için çok önemli olduğuna şüphe yoktur. Bu görev çok gizli olmalı, zira konsolos yanında tercümanını bile almadı, Sinop'ta sadece konsolosluğun şansölyesi kaldı. Peki, nereye gidiyor? Konsolos Bafra'ya Muhassıl Ağa'yı görmeye gittiğini söyleniyor. Başkaları da Kayseri'de Yusuf Paşa'yı görmeye gittiğini söylüyor. Kimileri de konsolosun madalyalar ve almak için Trabzon'a gittiğini söylüyor... Konuchenko Yusuf Paşa'yı görmeye gidecektir. Onun güvenini kazanarak Rusya'nın işine gelecek ayrıcalıkları elde edecektir. Belki de Gürcistan'daki Rus ordusu için girişimde olacaktır, belki de ondan geçmiş ile ilgili bazı bilgiler talep edecektir, belki de bizim buradan 
gönderilmemizi paşadan isteyecektir. Bu görevi daha evvel Tayyar Paşa nezdinde yapmıştı ama bunda başarılı olamamıştı... Konuchenco'nun Fransızlar aleyhinde bir girişimi olup olmadığını bilemiyoruz. Zaten mevcut siyasi ortam da buna uygun değildi. Sinop'ta bu derece etkin olan Rus konsolosunun bu gücünü ortadan kaldıran gelişme ise 1806 'da patlak veren Osmanl1Rus Savaşı oldu. Ruslar bu dönemde 1805 yılında imzalanan anlaşmaya göre Osmanlı Devleti ile müttefik bir durumdaydı. Fakat bu ittifak Bâb-1 Âli'yi oyalayan bir aldatmacaydı. ${ }^{126}$ Kasım 1806'da harekete geçen Rusların Hotin ve Bender'i alarak hiçbir direnişle karşılaşmadan tüm Eflak'ı işgal etmeleri üzerine Aralık ayında Bâb-1 Âli Rusya'ya savaş ilan etti. ${ }^{127}$ Rus elçisi İtalinski'ye Aralık ayının sonlarında, daha önceki büyükelçilere yapılan Yedikule'ye hapsedilme muamelesinin tersine İstanbul'u terk etme izni verildi ve İtalinski bir Rus gemisiyle İtalya'ya gitti. Kesilen bu diplomatik ilişkiler Konuchenco'nun Sinop’taki konsolosluğunu da askıya aldı. İtalinski örneğinde III. Selim Konuchenko'nun da Sinop'u terk etmesine izin verdi. Fakat Rus konsolosunun şehri terk etmesi o kadar da kolay olmadı. Bu süreçte Sinop kadısı Rus konsolosuna geçmişteki bazı olayları hatırlatır bir mahiyette zorluklar çıkardı ve şehri "üç gün" içinde terk etmesini istedi. Kadı, Konuchenko'ya sadece karayolu ile Sinop'u terk edebileceğini söyledi. Fourcade'a göre kadının bu tavrı bilinçli bir hareketti ve bu seyahat tarzı "karısı ve beş çocuğu olan Konuchenko" için hiç uygun değildi. Kadıdan, şehri terk etmemeleri durumunda şehirden çıkarılacaklarına dair tehdit alan Konuchenko eşyalarını ve ailesini Fourcade'a emanet etti ve bu konuda bir ilam hazırlad. ${ }^{128}$ Fourcade' in Sinop'taki en büyük rakibine bu şekilde bir merhamet göstermesi Sinop halkı arasında da şaşkınlık yarattı. Konsolos "Bu barbarlar alçak gönüllülüğü zayıflık olarak algılıyorlar" diyerek Sinopluların bu tutumunu eleştirmektedir. Aslında Fourcade, kendisini Ruslara karşı borçlu hissediyordu. Çünkü Hanya'daki on üç aylık esareti sırasında dört ay boyunca Rus konsolosunun yardımıyla hayatını idame etmişti ve İstanbul'daki tutukluluk halinin sona ermesinde Rus elçisinin de rolü vardi. ${ }^{129}$

Fourcade'ın konsolosluğunun Tayyar Paşa'dan sonra en dikkat çeken ikinci şahsı olan Konuchenco'nun Sinop'tan ayrılması aslında Fourcade'ın uzun zamandır görmek isteyeceği bir durumdu. Hatta bazı kaynaklar Fourcade'ın, Konuchenco'nun Sinop'tan çıkarılması için ayânlar ile işbirliği yaptığı belirtiliyordu. ${ }^{130}$ Konuchenco'nun Sinop'tan gitmesiyle Sinop'taki tek yabancı temsilci olarak kalan Fourcade artık tam bir özgürlük olacak; fakat bu özgürlük ortamı çok uzun sürmeyecekti. Bu şekilde 1803-1807 yılları arasında Sinop'ta, Fransız ve Rus konsoloslarının başını çektiği "taşra diplomasisi" dönemi, Konuchenko'nun 1806 'da çıkan savaş sonrası kesilen diplomatik ilişkiler, Fourcade'ın da Tilsit Antlaşması'yla oluşan Fransız karşıtı ortamda Kırım'a kaçması nedeniyle sona erdi.

\section{Sonrası Gelişmeler ya da Yalnızlık Dönemi}

Tayyar Paşa'nın 1805 Ağustos'unda Yusuf Paşa karşısında yenilerek Sohum'a sığınması Fourcade'ın tüm planlarını da tersine çevirdi. Yukarıda da değinildiği üzere konsolosun en önemli amacı Tayyar Paşa ile ilişkilerin kurulması ve onun himayesinde Fransız ticaretinin geliştirilmesiydi. Lakin Tayyar Paşa sonrası Anadolu'daki tablo Fourcade'ın 
başından beri görmek istemediği cinstendi. Bununla birlikte Tayyar Paşa'ya yaklaşmak için bu denli çaba harcayan Fourcade aynı çabayı daha sonra ne Yusuf Paşa ne de Çapanoğlu nezdinde göstermiştir. Konsolos bu iki güç ile sadece Sinop ve ziyaret ettiği yerlerdeki temsilcileri vasıtasıyla haberleşmiştir. ${ }^{131}$ Ayrıca 1807 yılının başlarında en büyük rakibi Konuchenco'nun etkisinden de kurtulmuştu. Fakat siyasi gelişmeler Fourcade'a Sinop'ta uzun süreli planlar yapma firsatı vermedi.

41 Tayyar Paşa'nın Anadolu'dan çıkarılması sonrası Fourcade'ın durumu hakkında tam bir değerlendirme yapamıoruz. Çünkü gerek Paris gerekse de Nantes'taki belgelerde Ağustos-Ekim 1805 arasında bir kesinti dönemi vardır. Yani bu kritik süreçte Fourcade'ın ne durumda olduğu hakkında bir değerlendirme yapmak zordur. Zira konsolosun Ekim ayındaki yazışmaları da bu durumu göstermektedir. Konsolos Anadolu'da ortaya çıan bu durum karşısında elçilikten yeni talimatlar beklediğini, içinde bulunduğu zor durumda elçiliğin daha fazla desteğine ihtiyacı olduğunu belirtiyordu. ${ }^{132}$ Gerçekten de bu karışıklıklar Sinop'ta da ortaya çıkmakta gecikmedi. Kastamonu müteselliminin şehri savunmak ve garnizona komuta etmek üzere Sinop'a gelmesi şehirde başını Sinop kadısı, Genç Mehmed Ağa ve Sinop müteselliminin çektiği kuvvetli bir muhalefet ortaya çıkardı. Mütesellimin Sinop kalesi içinde ikametini istemeyen bu muhalifler ona şehrin varoşlarında bir ikametgâh tahsis etmiş ve aksi durumda ona karşı direneceklerini beyan etmişlerdi. Hatta kadı da bu konuda bir ilam hazırlad. ${ }^{133}$ Muhtemelen bu süreçte mütesellim ile bu muhalifler arasında çatışmalar oldu. Çünkü Fourcade 22 Kasım 1805 tarihli raporunda Kastamonu müteselliminin şehri harabe halinde bırakıp gittiğini, şehirde zahire fiyatlarının üç misline çıtığını ve Rumların Kırım'a, Türklerin de İstanbul'a kaçmaya çalıştıklarını belirtiyordu ${ }^{134}$ Bunun yanında Fourcade'ın sıtmaya yakalanması ve karısının da hastalığı Fourcade ailesini Sinop'ta daha da zor bir duruma soktu. Fakat daha ilginci ise Fourcade'in 29 Ocak 1806 itibarıyla Kastamonu'da olmasıdır. Demek ki Fourcade, Rus konsolosu Konuchenko'nun Yusuf Paşa'yı görmek üzere Sinop’tan ayrılmasının kendisine sağladığı “özgürlük ortamını" değerlendirerek uzun zamandır görmeyi planladığı Kastamonu'ya bir seyahat gerçekleştirdi. Konsolos seyahatin amacını şu şekilde ifade ediyordu: ${ }^{135}$

Uzun zamandan beri Kastamonu şehrini görmeyi planlıyordum. Kastamonu'nun nüfusu, endüstrisi ve doğasının zenginliği bu şehri bizim ticaretimiz için önemli bir hale getirmektedir. Kastamonu Eyaleti'ni perişan eden karışıklıklar şimdiye kadar bana projelerimi gerçekleştirme ve mamul mallarımız ile takas edebileceğimiz ürünleri belirleme firsatı vermedi. Elçilikten gelen son mektup bana Trabzon limanını ziyaret etmemi ve bu tehlikeli yolculuğun raporunu bahara kadar göndermemi istedi. Kastamonu'da mütesellimin yakınlığından istifade etmeyi istiyorum.

42 Fourcade, Kastamonu'da gerek mütesellim ${ }^{136}$ gerekse de derebeyi olarak nitelendirdiği ağalar tarafından iyi bir şekilde karşılandı. Kastamonu hakkında istediği bilgileri elde etmekten ve bu ileri gelenlerin Fransız ticareti konusundaki olumlu yaklaşımlarından özellikle bahseden Fourcade, Kastamonu'nun Fransız ticareti için sunacağı imkânlar üzerinde durmaktaydı. Nüfusu elli binin üzerinde olan Kastamonu'da Fransız fesleri ve yünlülerinin önemli bir pazarı olduğunu gören konsolos şehrin yüksek tüketim potansiyeliyle birlikte Fransız ticaretine yeni pazarlar açabileceğini belirtiyordu. Eski değerlendirmelerinin aksine konsolos artık birden çok güç odağının ortaya çıktığı Anadolu'da bu ağalar ile iyi ilişkiler kurmaya çalışmakta ${ }^{137}$ ve elçilikten gerekli izinler konusunda yardım isteyerek Trabzon ve Ereğli'ye seyahat gerçekleştirmeye çalışmaktaydı. ${ }^{138}$ Fourcade Kostamonu'ya yaptığı bu seyahate ilişkin olarak elçiliğe çok 
geniş bir rapor hazırladığını belirtmekteydi. Bu raporda Fourcade, ticaret ile ilgili bilgileri Kastamonu'da mukim Alman koruması altında bir Katolik Ermeni'den, idari konulardaki bilgileri de bizzat mütesellimden almıștı. Bunun yanında hazırladığı rapor iklim, coğrafya, yer altı kaynakları ve antik eserler konusunda da bilgiler içeriyordu. ${ }^{139}$ Fourcade 12 Mart'ta elçiliğe "Kastamonu Vilayeti'nin Yönetim, Vergiler, Üretim ve Ticareti" hakkında bir rapor hazırlayıp gönderdiğini belirtse de bu rapor ne kullandığımız tasniflerde bulunmakta ne de Fourcade'un diğer "mémoire" ları gibi ayrıca yayınlanmıștır. ${ }^{140}$ Fourcade Fransız ticareti konusunda iyi izlenimler edindiği Kastamonu'dan Mart ayının ortalarında Sinop'a döndü. Fakat burada hiç ummadığı bir manzara ile karşılaştı. Daha Sinop'a varmadan İnebolu'da konsolosluğun Rum denizciler tarafından saldırıya uğradığı haberini aldı. Konsolos Kastamonu'ya uzun ve yorucu bir yolculuk yapacağı için yanına sadece Tercümanı Simian'ı ve bir de yeniçerisini almış ve konsolosluğu da şansölye Bernage'a teslim etmişti. "Hasta halde bırakmış olduğu eşinin ve 5 yaşındaki çocuğunun dört geminin mürettebatı tarafından saldırıya uğramasının" hiç aklına gelmeyeceğini belirten Fourcade bunun Fransız ulusuna karşı olan bir kıskançlığın tezahürü olarak tarif eder. 7 şubat'ta gerçekleşen bu saldırıda hizmetçilerinden biri öldürülmüş ve ailesi ve konsolosluğun şansölyesi Bernage ciddi bir şekilde tehdit edilmişti. Suçluların cezalandırılması konusunda gerek yerel idareciler gerekse de elçilik nezdinde Fourcade ve Bernage'ın pek çok girişimi oldu. Fakat saldırı sırasında Fourcade'ın Sinop'ta olmaması ve Sinop'taki idarecilerin de kayıtsızlığ yüzünden bu soruşturmadan Fourcade istediğini alamamış gözükmektedir. ${ }^{141}$ Bunun yanında konsolos, konsolosluk binasının Türk mahallesine yarım saat kadar uzaklığı nedeniyle Sinop'taki otoriteleri, Erzurum taraflarında olması nedeniyle de Rus konsolosu Konuchenco'yu suçlamaz. Lakin saldırının müsebbibi olan Rumlara olan güvensizliği ise daha da artar. ${ }^{142}$ Fourcade, bu süreçte ailesi ve konsolosluğu iyi bir şekilde koruyan şansölye Bernage ${ }^{143}$ için elçilik nezdinde bazı girişimlerde bulundu. Kastamonu Amasya, Samsun ve Tokat'ta Fransız ticaretini geliştirmek için buraların üretimini, zenginliğini ve hatta halkın önyargılarını bilen görevlilere ihtiyaç olduğunu ve üç seneden beri Sinop'ta bulunan Bernage'in bu yerlerden birine tayin edilebileceğini teklif ediyordu. ${ }^{144}$ Fourcade'ın bu ricasını Bernage'a olan vefa borcu veya Anadolu ticaretinin gelișeceği yönündeki inancına bağlamak mümkündür. Takip edebildiğimiz oranda Fransız Dışişleri'nden bu teklife uygun bir cevap gelmedi; fakat Fourcade bölgeye ilişkin gözlemler yapmak için 1806'nın yazında altı yıllık konsolosluğunun en geniş seyahatini gerçekleştirecekti.

Fourcade'ın bu umutlu bekleyişine rağmen Kuzey Anadolu'da Tayyar Paşa sonrasında hâkim olan kargaşa ortamı devam etmekteydi. Özellikle Tayyar Paşa'nın taraftarlarının yoğun olduğu Canik'te sıkıntılar yaşanmaktaydı. Tayyar Paşa'nın taraftarları pek çok şehri, özellikle de Bafra'yı ele geçirmiş ve Yusuf Paşa'nın mütesellimini de şehirden çıarmıştı. Bunun yanında Yusuf Paşa da Tayyar Paşa'nın destekçilerine karşı bir savaş açmıştı. Fourcade'a göre Tokat, Merzifon, Lâdik, Vezirköprü, Amasya ve Niksar'ın ileri gelen zenginleri Tayyar Paşa'nın adamları olmakla suçlanarak etkisiz hale getirilmişlerdi. ${ }^{145}$ Yusuf Paşa'nın bu baskı politikası büyük bir tepki toplamış ve Çarşamba, Ünye ve Samsun'da başında Hazinedaroğlu Süleyman Ağa'nın ${ }^{146}$ bulunduğu bir muhalefet ortaya çıkmıştı. Yusuf Paşa'nın Bafra'da olan Kâhyası Selim Ağa, konağında muhasara edilmiş ve Bafra'dan çıkarılmıştı. Fourcade'a göre Süleyman Ağa'nın kırk bin kişilik bir silahlı gücü vardı. Aralarında Ünye hâkimi İbrahim Bey, Eski Sinop Mütesellimi Süleyman Ağa, Samsun Ağası Hacı Emin ve Bafralı Küçük Ahmet'in 
olduğu muhalifler Yusuf Paşa'nın neden olduğu sefalet ve zorbalığı ileri sürerek Bâb-1 Âli'den azlini talep etmişlerdi. ${ }^{147}$ Canik tarafındaki bu karışıklığa rağmen Kastamonu'da tam bir sükûnet hâkimdi. Fourcade konsolosluk bölgesinin bu durumundan endişeleniyor ve hükümetin bu duruma müdahale etmemesi durumunda Karadeniz'in bir çöl haline geleceğini belirtiyordu. ${ }^{148}$ Konsolos Karadeniz sahillerine hâkim olan bu anarşi ortamı hakkında şu bilgileri vermektedir. ${ }^{149}$

Ünye, Giresun ve Samsun bu dönemde önemli kayıplar yaşadı. Samsun halkı bundan çok fazla etkilenmedi; çünkü bu durumdan korkan halkının bir kısmı kendilerine verilen sözlere inanarak şehirden ayrıldı. Pek çok tüccar ve özellikle bu iskeledekiler ülkeyi terk etmek zorunda kaldı. Bütün sahil harabe haline geldi. Özellikle Ünye'de Yusuf Paşa'nın adamları Sicilyalı haydutlar ve Rus kazaklarını aratmayacak derecede yıkımlar yapmışlardı Türk Müslüman yabancı masum, suçlu hepsi birden kurban edildi. Dört binden fazla kişi bu durumdan kaçmak için 18 büyük ve bir o kadar da küçük gemiye binmiş ve Allahtan Kastamonu mütesellimi tarafından yönetilen Sinop'a sığınmışlardır.

Bu süreçte Sinop halkının göstermiş olduğu misafirperverlik Fourcade'ın özellikle takdirini kazandığı gibi Rus konsolosunun bu zavallılar arasından Kırım'a göçmen elde etmeye çalışmasını da eleştirmekteydi. Fourcade bunun gibi bölgedeki karışık ortam hakkında raporlar göndermeye devam etti. ${ }^{150}$ Aslında konsolosun Sinop dışına çıkarak yeni incelemeler yapma yönünde planları vardı. Fakat konsolosun sıtmadan kaynaklanan rahatsızlığına bir mağaraya düşmesi sonucu omuzunu incitmesi de eklenince uzun bir süre Sinop'tan çıkamadı. ${ }^{151}$ Fourcade'ın raporlarında belirttiği gibi, sebebinin sağlık sorunlar $1^{152} \mathrm{~m} 1$ yoksa daha evvel planlarını yaptığı gibi görmek istediği yerler mi olduğunu tam olarak bilemesek de konsolosun 1 Ağustos'ta Gerze; 5 Ağustos'ta Bafra'da olduğunu görüyoruz. ${ }^{153}$ Gerçekten de Fourcade Temmuz ayının sonlarından Eylül'e kadar devam edecek olan ve konsolosluk süresince en geniş seyahatini gerçekleştirmek üzere Sinop'tan ayrılmıştı. Fourcade iki ay süren bu seyahatte Bafra, Vezirköprü, Havza, Lâdik, Merzifon ve Amasya'yı ziyaret etti. ${ }^{154}$ Fourcade bu seyahatlerine ilişkin olarak günümüze kadar bazıları yayınlanmayan önemli raporlar "mémoire" hazırladı. Bu raporlar Fourcade'ın antikiteye olan merakı yüzünden verdiği tarihi bilgiler açısından önemli olduğu kadar konsolosun Anadolu'nun ticari durumu üzerine yaptığı değerlendirmeler açısından da önemlidir. Fourcade Anadolu'da Rus ve İngiliz malları karşısında Fransız mallarının nasıl bir geleceği olduğunu, Fransız tüccarların Anadolu'da kaybettikleri pazarları nasıl tekrar kazanabileceklerine yönelik tavsiyelerde bulunuyordu. Fourcade Eylül'de tekrar Sinop'a döndü. Zira Fourcade Ekim ayının ortalarında İran'da şahı nezdindeki görevinden dönem Amédée Jaubert ile birlikte İnebolu'dadır. ${ }^{155}$ Fourcade'ın Sinop'a döndükten sonraki faaliyetleri hakkında ayrıntılı bilgi vermek zordur. Çünkü 1807 yılındaki faaliyetleri hakkında, seyahat raporlarının hazırlanmasının dışında ne Paris ne de Nantes'daki arşivlerde bu döneme ilişkin belgeler yer almamaktadır. ${ }^{156}$ Bununla birlikte 1807 yılının sonlarında karşımıza çıan en önemli gelişme ise 11 Aralık 1807'de konsolosluğun yeni bir saldırıya uğraması oldu.

1807'nin sonunda konsolosluk Fourcade ve şansölye Bernage da burada bulunduğu bir zamanda bir önceki saldırı ile mukayese edilmeyecek ciddi bir saldırıya uğradı. 1807 yılının Mayıs'ında Sultan III. Selim'i tahtan indiren yeniçeriler ve tutucu güçlere katılan ve memleketlerine dönen Trabzon, Rize ve Faş'lı Lazları taşıyan gemiler fırtına nedeniyle Sinop limanına sığınmak zorunda kalınca Sinop'ta bu kez aktörleri Rum denizciler değil de Lazlar olan yeni bir anarşi ortamı başladı. Fourcade'ın 26 Aralık 1807 
tarihinde Elçi Sebastiani'ye yazdığı rapora göre Laz denizciler Sinop'a gelerek şehrin kahvelerine yayılmışlar ve 11 Aralık sabahı konsolosluk binası etrafına gelerek burayı kuşatmışlar ve Fourcade ve Bernage'ı ciddi bir şekilde yaralamışlardı. Lazlar şehirdeki Fransızlara oldukça kötü davranmış ve Bâb-1 Âli'yi de Rumeli'yi Ruslara satmakla suçlayarak şehirde tam bir anarşi ortamı oluşturmuşlardır. Fakat daha da ilginci Sinop müteselliminin bu olaylar karşısındaki kayıtsızlığıydı. Mütesellim konsolosluk binasında yaralı halde olan Fourcade'ın güvenliğini sağlayamayacağı gerekçesiyle onu kale içine taşımayı teklif etmiş ama konsolosun Rum eşi her tarafı sarmış olan bu isyancıların içinde Fourcade'ın konsolosluk binasından çıarılmasını reddetmişti. Mütesellim'in daha ilginç bir hamlesi de bu süreçte tutuklanan suçluların serbest bırakılması ve hadisenin ertesi günü de şehri terk etmelerine göz yummasıdı.. ${ }^{157}$ Fourcade her ne kadar bu hadisenin peşinden gidip Bernage'ı sırf bu konuyu takip etmek için İstanbul'a gönderse de ne Sebastiani ne de halefi Latour-Maubourg'dan bu konuda bir destek göremedi. Bu hadisenin Fourcade'ın Sinop konsolosluğunun geleceğini göstermesi açısından önemli bir dönüm noktası olduğunu belirtmek gerekir. Zira Fourcade artık şehirde ciddi bir güvenlik endişesi yaşamaya başlayacak ve her firsatta Sinop'u terk etmek için uygun bir zemin arayacaktır. ${ }^{158}$ Çünkü İstanbul'daki gelişmeler Anadolu'ya da yansımaya başlamıştır. Canik taraflarındaki karışıklıklar bu kez Amasya ve Kastamonu'ya da sirayet etmiş ve Fourcade'in konsolosluk bölgesi konsolosun beklentilerinin aksine yeni bir kargaşa devresine girmiştir. ${ }^{159}$ Bunlara ilaveten 1806 'da başlayan Osmanlı-Rus Savaşı da Karadeniz ticaretinde neden olduğu gerileme ve Fransız-Rus yakınlaşmasının kamuoyunu Fransızlar aleyhine çevirmesi de Fourcade endişelendiren diğer gelişmeler olarak konsolosluğunun sona ermesinde etkili olan sebepler oldu. ${ }^{160}$

\section{Konsolosluğun Meyveleri: Fourcade'ın Bilimsel Çalışmaları}

Anadolu'nun bu karışık siyasi ve askeri yapısı içinde büyük beklentiler içinde Sinop'ta bir konsolosluk kurarak Fransız ticareti için yeni pazarlar arayan Fourcade'in bu doğrultudaki çalışmalarını bir yana bırakacak olursak konsolosluğunun belki de daha verimli olan "bilimsel" tarafını değerlendirmek gerekmektedir. Yukarıda da değindiğimiz gibi iyi bir eğitim alan Fourcade her firsatta asıl görevinin yanında bu yeteneğini ortaya çıkarmak için eline geçen her firsatı değerlendirmeye çalışıyordu. Gerçekten de Fourcade Sinop dışında gerçekleştirdiği seyahatlerde iyi bir "ticari komiser" olarak ziyaret ettiği yerlerin ticaret, endüstri ve tarımından bahsetmenin yanında bu yerlerin coğrafyası, antik dönemdeki tarihi ve arkeolojisi ile ilgili incelemelerde de bulunuyor; seyahat güzergâhlarına dair haritalar hazırlıyor ve bir nümizmat gibi bulduğu eski paraları topluyordu. ${ }^{161}$ Raporlarından da anlaşıldığı gibi seyahatleri sırasında elde ettiği izlenimleri bir günlükte kaydediyor ve seyahatleri sonrasında Sinop'ta bu izlenimleri düzenleyerek birer "mémoire" haline getiriyordu. Fourcade yazışmalarında İstanbul'daki elçilik ile bağlantı kurmadan doğrudan Paris ile haberleşiyor; bu da elçiliğin öfkesine neden oluyordu. Bundan dolayı Fourcade'ın Fransa'ya gönderdiği raporlar İstanbul'da alıkonuyor ve burada yazarları olan Fourcade'1 incitecek şekilde hor görülüyordu. ${ }^{162}$ Gerçekten de Burune ve Ruffin'den sonra Sebastiani'nin elçilik dönemlerinde Fourcade'ın yazışmaları önemsiz ve işe 
yaramayan belgeler olarak muamele görmeye başliyor ve bu da Fourcade'ı ciddi şekilde incitiyordu. ${ }^{163} \mathrm{Bu}$ şekilde elçilik tarafından beklediği ilgiyi görmeyen raporları karşısında Fourcade yaptığı çalışmaların arkasında durarak Anadolu'nun bilimine ve sanatına olan aşinalığın her şey ile ilişkili olduğuna inanıyordu. ${ }^{164}$ Fourcade özellikle raporlarında önemli bir yer tutan coğrafya ve tarihi kısımlar hakkında elçiliğe şu açıklamaları yapıyordu: ${ }^{165}$

Benin antikite, coğrafya ve botanik ile ilgili gözlemlerimin raporumu dolduran çalışma dışı bir kısımlar olarak görmeyeceğinizi düşünüyorum. Kesinlikle kendimi bir Tournefort gibi görme iddiasında değilim. Fakat onun M. Pontchartrain ile olan yazışmalarını takip edilecek bir model olarak görüyorum. Benim bilgilerimin bu ünlü bilginin bilgileriyle mukayese edilemeyeceğini biliyorum... Bilinmeyen bu yeni ülkenin üretimi konusundaki gözlemlerim belki Journal de l'Empire'de yayınlanabilir. Fakat bu ülkenin ticaretinin durumu herkesi ilgilendirmeyebilir, bu durumda ben bu çorak bir ülkeye bir kaç çiçek ekiyorum. Sizden benim tahmin etmediğim bir engel çıkmaz ise hazırladığım bu raporların coğrafya ve antikite ile ilgili kısımlarının enstitü tarafindan yayınlanmasına izin vermenizi rica ediyorum.

şüphesiz Fourcade'ın bilimsel çalışmaları bakımından en verimli yılı 1806 yılı oldu. Her ne kadar daha önce 1805 yılında Sinop dışına çıksa da bu dönemde en önemli faaliyeti Tayyar Paşa ile ilişkilerin tesis edilmesiydi. Fakat Tayyar Paşa'nın sürgüne gönderilmesi sonrasında Fourcade asıl görevi konusunda bir belirsizlik dönemine girmekle birlikte bu ortam Fourcade'a konsolosluk bölgesini keşfetmek ve bazı coğrafi ve arkeolojik incelemeler yapma firsatı da sağlamıştır. ${ }^{166}$ Fourcade 1806 yılının kışında ve ilkbaharında Sinop'un güneyine inerek burada Kızllırmak ve Göksu vadilerini gezerek Kastamonu'ya ulaştı. Bu bölgelerde yaptığı incelemelerini "Mémoire sur Pompeïopolis ou Tasch Kouprou avec quelques remarques sur Tovata ou Voyavat" ${ }^{167}$ ve Mémoire sur Castambol ou Castamouni ${ }^{168}$ adında iki rapor halinde hazırladı. Fourcade yapmış olduğu bu geziler sayesinde bölge ile ilgili haritaların çok büyük yanlışlar barındırdığını ve bu bakımdan faydalı olabileceğini düşündüğü bir harita yaptığını ifade etmektedir. ${ }^{169}$

Fourcade 1806 yazında daha geniş ikinci bir seyahate çıktı. Bu seyahatinde Vezirköprü, Havza, Ladik, Merzifon ve Amasya'yı ziyaret etti. Konsolos bu seyahatlerine ilişkin olarak bir kısmı Dışişleri Bakanlığı'nın konsolosluk yazışmalarında bir kısmı da Memoirs et Documents tasnifinde yer alan raporlar hazırladı. Bunlardan ilki Vezirköprü hakkındadır. "Ville et territoire de Vezir-Kioprou" başlığını taşıyan bu raporda Fourcade büyük oranda Vezirköprü'nn iktisadi vaziyeti hakkında değerlendirmeler yapmanın yanında buranın antik dönemine ilişkin olarak da bazı bilgiler veriyordu. Aynı şekilde, "Ville et territoire de Ladick" Ladik üzerine özellikle Ladik'in iktisadi yapısı ve coğrafyası üzerinde değerlendirmelerin olduğu bir rapor hazırladı. ${ }^{170}$ Vezirköprü ve Ladik'ten sonra Fourcade en detaylı incelemeleri Amasya üzerine gerçekleştirdi. Zira Amasya hakkında daha fazla rapor hazırladığı görülmektedir. Bu raporlar Memoirs et Documents kataloğu altında yer almaktadır. ${ }^{171}$ Fourcade'ın bu ayrıntılı çalışmaları sadece bu yerler ile sınırlı değildir. Fourcade'ın Sinop üzerine de ayrıntılı raporlar hazırladığı görülmektedir. Fourcade konsolosluğun bu ilk dönemlerinde bölgedeki siyasi hadiseleri ve ticari meselelerin yanında başka konularda da incelemeler yapıyordu. Bu konuda 26 Pluviôse An 12/16 şubat 1804 tarihli raporunda, elçiliğe gönderilmek üzere Sinop hakkında ayrıntılı bir rapor, "mémoire statistique sur la ville de Sinope \& des environ état physique \& moral de pays, relation établies au possible avec l'intérieur de l'Asie, description de restes d'antiquité" 
hazırladığını yazıyordu. ${ }^{172}$ Fourcade'ın Sinop üzerine hazırladığı "La situation politique et militaire de Sinope, (1807)" adlı rapor elimizde olsa da "Mémoire sur Sinope" adlı Sinop’un antik geçmişi üzerinde önemli bilgiler verdiği ifade edilen raporu ise kayıptır. 173

Her ne kadar yukarıda bahsettiğimiz bu raporların bir kısmı elimizde olmasa da en azından kendi yazışmalarından Fourcade'ın daha detaylı çalışmalar ile meşgul olduğu ve eline geçen her firsatta konsolosluk görevi yanında bir arkeolog gibi çalışmalar incelemeler yaptığı anlaşılmaktadır. Tespit ettiğimiz gibi bu merak sadece Sinop dışındaki incelmelerde değil Sinop'ta da görülebilecek türdendi. Bir arkeolog gibi çalışmasının yanında hazırlamış olduğu ayrıntılı haritalar ve limanlar konusundaki incelemeleri de özellikle kayda değerdir. Fourcade bölgedeki siyasi gelişmeler hakkında da "Situation Politique de l'Asie mineure" ve "Bulletin de la Province de Djanick" gibi raporlar da hazırlıyordu. 19. yüzyılın başlarında, Orta Karadeniz Bölgesi için oldukça önemli bilgiler ihtiva eden bu raporlar ayrı bir çalışmanın konusu olmayı hak edecek derecede uzun ve ayrıntılı bilgiler vermektedir. Çünkü bunlar Fourcade'ın da belirttiği gibi coğrafya, ticaret, tarım, endüstri ve arkeolojik kaynaklar olmaları bakımından daha genel bir çerçevede değerlendirilmesi gereken kaynaklardır. Buradan hareketle Fourcade'ın raporlarının şimdiye kadar sadece arkeolojiyi ilgilendiren birer kaynaklar olmaktan çıkarılıp Sinop merkezli olarak Orta Karadeniz'in 19. Yüzyılın başlarındaki durumu, Osmanlı Fransız ilişkilerinin Karadeniz'deki ilk yansımaları ve Karadeniz'deki Rus etkisi üzerine hazırlanacak olan çalışmalar dâhil edilmesi gerekmektedir. Bu şekilde bölge tarihi için var olan önemli bir boşluğun doldurulması mümkün olabileceği gibi bu güne kadar yerli araştırmacılar tarafından ihmal edilen bu kaynakların da kullanılması yapılacak olan araştırmaların niteliğini de olumlu yönde etkileyecektir.

\section{Sonuç}

Tayyar Paşa'nın 1805'te iktidardan düşmesi sonrasında Anadolu'daki kargaşa ortamı, arkasından 1806 yılında başlayan Osmanlı-Rus ile Karadeniz ticaretindeki yavaşlama ve nihayetinde de Rusya ve Fransa arasındaki Tilsit Antlaşması sonrasında ortaya çıkan tablo artık Fourcade'ın konsolosluğunun ve Sinop'taki misyonunun başarısız olacağını göstermeye başlamıştı. Bu etkenlere bir de kendisini 1807 yılındaki saldırıda da gösteren Fransız karşıtı hava eklenince Fourcade artık Sinop'tan çıkmanın hesaplarını yapmaya başlayacaktı. Özellikle İstanbul'dan gelen gemiler başkentte gelişen hadiseleri Sinop'a yayıyor ve Fransızları Osmanlı donanmasını el geçirmek ve Rus dostu olmakla suçluyordu. ${ }^{174}$ Bundan dolayı Fourcade, elçi Sebastiani'den daha fazla yardım istiyor ve Sinop'taki bu atmosferin çok yakın bir zamanda kendilerini de kurban edeceğini belirtiyordu. Gerçekten de Fourcade'ın son yazışmaları onun Sinop'taki tedirgin halini çok iyi bir şekilde yansıtmaktadır. Gerek bu güvensiz ortam gerekse de Fourcade'ın sağlık sorunları konsolosu Sinop'tan çıkmaya zorlamaya başlamıştır. 1808 yılına ilişkin olarak elimizde olan sınırlı yazışma da Fourcade'ın Sinop'tan çıkmak için uygun bir fırsatı kolladığını göstermektedir. Bu maksatla Fourcade Kırım'dan gelen gemiciler ile görüşüyor ve buradaki durum hakkında bilgi almaya çalışıyordu. Konsolosluğun şansölyesi Bernage ise daha önce 1807'deki saldırıya ilişkin olarak İstanbul'a gitmişti. Bernage'ın bir daha Sinop'a dönmediği anlaşılmaktadır. Fourcade ise 1809'un kışını da Sinop'ta geçirmek zorunda kaldı. Nihayetinde ise Fourcade, konsolosluğu, kapanacağ 1 
1812'ye kadar idare edecek olan Simian'a ${ }^{175}$ teslim ederek 17 şubat'ta, Fransız bandırası taşıyan bir Rum gemisiyle ailesiyle birlikte gizlice Sinop'tan kaçmış ve 22 şubat'ta Kefe'ye ulaşmıştır. Fourcade'a göre İstanbul'a bir şekilde ulaşmanın en kolay yolu Kefe'ye sığınmaktı. ${ }^{176}$ Fakat Fourcade'ı Kırım'da da bazı zorluklar bekliyordu. Fourcade Kefe'de gözaltına alınacak ve burada kendi tabiri ile "bir savaş esiri muamelesi" görecekti. ${ }^{177}$ Nisan'in sonuna kadar Kefe'de kalan konsolos buradan Viyana'ya gitmiştir. 178

51 Fourcade'ın Sinop konsolosluğunun kaderi de daha 1803'te Ereğli'yi terk eden Alllier gibi oldu. Aslında Fourcade da bu sonun farkındaydı ve bunun için konsolosluğunun son dönemlerinde Sinop için değil de Trabzon'da Dupré için endişeleniyordu. Konsolosun konsolosluk bu kaygısı bile sadece Fransızların Sinop'ta genel bir tercihlerini sorgulamamız açısından yeterlidir. Bu iki konsolosun tecrübelerinin de gösterdiği ne Ereğli ne de Sinop Anadolu ile Fransa arasında gerçekleşecek bir ticarette birer ticaret merkezi olma potansiyeli taşımıyorlardı. Bu kargaşa ortamında daha fazla direnen Trabzon'daki konsolos Dupré'nin durumu da aslında pek farklı değildi. Uzun bir süre Trabzon'da kabul görmeyi bekleyen Dupré burada pek çok zorlukla mücadele edecek; fakat öleceği tarih olan 1822'ye kadar Trabzon'daki görevinin başında kalacaktı. ${ }^{179} \mathrm{Bu}$ dönemde Trabzon'un da tam olarak Fransızların beklentilerini karşıladığını söylemek zordur. Trabzon'un gerçek bir transit ticaret mahalli haline gelmesi için 1830'lu yıllara kadar beklemek gerekecekti. Sonuç olarak Fourcade'ın altı yıllık Sinop konsolosluğu büyük ticari beklentilere karşılık veremedi. Fakat konsolosun bilimsel merakı ile geriye bırakmış olduğu raporlar ve konsolosluğu süresince Sinop ve çevresinde gelişen hadiseleri düzenli olarak aktardığı elçilik ve dış işleri ile yaptığı yazışmalar bu gün bize, özelde sinop genelde de çevresi için değerlendirilmeyi bekleyen geniş bir kaynak yı̆̆ını bıraktı.

\section{BIBLIOGRAPHIE}

Bacqué-Grammont Jean-Louis, Kuneralp Sinan, Hitzel Frédéric, (1991) Représentants Permanents de la France en Turquie (1536-1991) et de la Turquie en France (1797-1991, Istanbul : Éditions Isis.

Bilici, Faruk, (Dir. F. Bilici, I. Candea, A. Popescu) (2007) « La France et la mer Noire sous la Restauration ", Enjeux Politiques, économiques et Militaires en mer Noire (XVe-XXI è̀cles), Brailla : Éditions Istaros, p. 655-676.

Bilici Faruk, (2003) « La France et la mer Noire sous le Consulat et l'Empire : "la porte du harem ouverte" ", Méditerranée, Moyen-Orient : deux siècles de relations internationales, recherches en hommages à Jacques Thobie (dir. W. Arbid, S. Jançal, J.-D Mizrahi, S. Saul), Paris : L'Harmattan. Bilici Faruk, (1992), La politique française en mer Noire (1747-1789): vicissitudes d'une implantation, İstanbul : Isis.

Coquelle Paul, (1903) « La Mission de Sébastiani à Constantinople en 1801 », Revue d'Histoire Diplomatique, Dix-Septième année, Paris. 
Cumont Franz, (1927) « Pascal Fourcade, explorateur de l'Asie Mineure », Comptes rendus de l'Académie des inscriptions et belles lettres, 4.

Déhérain Henri, (1924) «Les premiers consuls de France sur la côte septentrionale de l'Anatolie », Revue de l'histoire des colonies françaises, 17, p. 301-380.

Duparc Pierre, (1869) Le Recueil des instructions données aux ambassadeurs et ministres de France, Turquie, Tome xxIx, Centre National de la Recherche Scientifique, Paris, p. xxIV-Xxv.

Herbette Maurice, (1902) Une ambassade turque sous le Directoire, Paris.

Kasaba Reşat, (1993) Osmanl İmparatorluğu ve Dünya Ekonomisi, çev. Istanbul : Kudret Emiroğlu, Belge Yayınları.

Levasseur Émile, (1912) Histoire du commerce de la France, Paris.

Raccagni Michelle, (1980) “The French Economic Interests in the Ottoman Empire”, International Journal of Middle East Studies, vol. 11/3.

Saint-Priest François-Emmanuel Guignard de, (1877) Mémoires sur l'ambassade de France en Turquie et sur le commerce des Français dans le Levant, Paris : INLCO.

Shaw Stanford J, (2008) Eski ve Yeni Arasında Sultan III. Selim, çev. Hür Güldü, Istanbul: Kapı Yayınları.

Soysal İsmail, (1999) Fransız İhtilâli ve Türk Fransız Diplomasi Münasebetleri (1789-1802), Ankara : TKK. Ubucini Abdolonyme, (1853) Lettres sur la Turquie, Paris : Librairie Militaire de J. Dumaine.

\section{NOTES}

1. Franz Cumont, "Pascal Fourcade, explorateur de l'Asie Mineure », Comptes rendus de l'Académie des inscriptions et belles lettres, 4 (1922), p. 308.

2. Reşat Kasaba, Osmanlı İmparatorluğu ve Dünya Ekonomisi, çev. Kudret Emiroğlu, Belge Yayınları, İstanbul, 1993, s. 33.

3. 1787-1789 yıllarında Fransızların Osmanlı ülkesine ihracatı 39,9 ve ithalatı 19,5 milyon frank iken bu rakamlar 1797-1799 arasında ise ihracatta 5,2; ithalatta ise 3,8 milyon franka düşmüştür. Émile Levasseur, Histoire du commerce de la France, Paris, 1912. p. 19 ; M. A. Ubucini, Lettres sur la Turquie, Librairie Militaire de J. Dumaine, Paris, 1853, p. 404-405 ; Michelle Raccagni, "The French Economic Interests in the Ottoman Empire", International Journal of Middle East Studies, vol. 11/3 (1980), p. 342.

4. Maurice Herbette, Une ambassade turque sous le Directoire, Paris 1902, p. 248-284.

5. J.-L. Bacqué-Grammont, S. Kuneralp, F. Hitzel, Représentants Permanents de la France en Turquie (1536-1991) et de la Turquie en France (1797-1991), Éd. Isis, İstanbul, 1991, p. 48-49.

6. Sebastiani'nin İstanbul'daki görevi için bkz. Stanford J. Shaw, Eski ve Yeni Arasinda Sultan III. Selim, çev. Hür Güldü, Kapı Yayınları, İstanbul, 2008, s. 473-474; P. Coquelle, «La Mission de Sébastiani à Constantinople en 1801 ", Revue d'Histoire Diplomatique, Dix-Septième année, Paris, 1903, p. 438-455.

7. İsmail Soysal, Fransız İhtilâli ve Türk Fransız Diplomasi Münasebetleri (1789-1802), TTK Ankara, 1999, s. 315-327.

8. I. Soysal, a.g.e., s. 332-334.

9. Anlaşmanın ikinci maddesi ile Karadeniz'de serbestçe ticaret hakkı kazanan Fransa üçüncü madde ile de bu ticaretin koruyucu ve uygulayıcıları ticari çıkarları için gerekli gördüğü yerlere görevliler veya ticari kömiserlikler kurma hakkı kazanıyordu. 6 Messidor An 10/25 Haziran 1802 
tarihli Fransız-Osmanlı Antlaşması için bkz. Comte de Saint-Priest, Mémoires sur l'ambassade de France en Turquie et sur le commerce des Français dans le Levant, Paris, 1877, p. 523-537.

10. Les Affaires étrangères et le corps diplomatique français, De l'Ancien Régime au Second Empire, Tome I, Éditions du C.N.R.S., Paris, 1984, p. 394.

11. Aynı eser, s. 398-399.

12. Kusurlarına rağmen konsolosluk ağı yerel koşullara göre oldukça esnek bir yapıdaydı. Bu konuda örnek olarak Kahire'deki genel konsolosluk ülkedeki karışıklıklar nedeniyle 1777'de İskenderiye'ye taşındı. Mesela Bağdat ve Basra'daki konsolosluk teşkilatları konusunda hükümet bazı çekilşiki uygulamalar yaptı. 1741'de Bağdat'ta kurulan konsolosluğun amacı Hindistan ile olan ticari ilişkileri kolaylaştırmak, güçlü Bağdat paşaları nezdinde bir ilişki kurmak, İngiliz ve Hollanda mallarının XVIII. yüzyıldan itibaren var olduğu bu taraftaki pazarlarda Fransız mallarına bir yer aramak ve buradaki dini etkinliği misyonerler vasıtası ile tesis etmekti. 1781'de bu konsolosluk Basra'ya taşınsa da devrim döneminde bu konsolosluk yeniden Bağdat'a taşındı. Bkz. Amaury Faivre d'Arcier, Les oubliés de la liberté. Négociants, consuls et missionnaires français au Levant pendant la Révolution (1784-1798), Peter Lang, Paris-Bruxelles 2007, p. 64.

13. F. Bilici, «La France et la mer Noire sous le Consulat et l'Empire: "la porte du harem ouverte" ", Méditerranée, Moyen-Orient: deux siècles de relations internationales, recherches en hommages à Jacques Thobie (dir. W. Arbid, S. Jançal, J.-D. Mizrahi, S. Saul), L'Harmattan, Paris, 2003, p. 60.

14. Bu konuda bkz. F. Bilici, La politique française en mer Noire (1747-1789): vicissitudes d'une implantation, Isis Pres, İstanbul, 1992; Karadeniz'e yönelik Fransız ilgisinin bir neticesi olarak hazırlanan ve Karadeniz'in ticari potansiyelini ortaya koyan çalışmalar Sinop'tan da bahsetmekteydi. 1787 yılı baskılı bir kitapta Sinop'un ticareti ayrıntılı bir şekilde işlenmişti. Burada Sinop limanına giren çıkan malların cinsleri ve değerleri ve Sinop'un önemi hakkında bilgi bulmak mümkündür. Esere göre Sinop'un en önemli özelliği tersane adına şehirde gemi yapımının gelişmiş olmasıydı. Fakat şehrin nüfusuna ilişkin olarak verilen rakamlar oldukça yüksektir. Eserde 3-4 bini reaya olmak üzere eser 60 bin kişilik bir şehirden bahsetmektedir. Bkz. Observations sur le commerce de la mer Noire et des pays qui la bordent auxquelles on a joint deux mémoires sur le commerce de Smyrne et de l'Isle de Candie : ouvrages composés sur les lieux mêmes, Paris, 1787, p. 202-224.

15. Pierre Duparc, Le Recueil des instructions données aux ambassadeurs et ministres de France, Turquie, Tome XXIX, Centre National de la Recherche Scientifique, Paris, 1869, p. XXIV-XXV.

16. F. Bilici, La France et la mer Noire, p. 58.

17. Ibidem.

18. Bazı belgelerde Konsolosun adı Kognuschenko olarak geçmektedir. Bkz. AMAEF, CADN, Constantinople, Ambassade, Série D, Correspondance avec les Échelles, Sinope, Nu. 3, Fourcade'dan General Brune'e, 24 Vendémiaire An 12/17 Ekim 1803 (1Kullandığımız belgelerde 24 Kasim 1793 ve 1 Ocak 1806 arasında geçerli olan Fransız Devrim Takvimi yazılmış ve bunlar tarafımızdan Gregoryen takvimine çevrilmiştir); F. Bilici ise konsolosun adını Manouchenko olarak vermektedir. F. Bilici, La France et la mer Noire, p. 64.

19. M. E. Martin, "Some miscellaneous notes on the town and antiquities of Sinop, mainly from travellers' accounts”, Anatolian Studies, 48 (1998), pp. 175-180; F. Cumont, "Pascal Fourcade, explorateur de l'Asie Mineure ", Comptes rendus de l'Académie des inscriptions et belles lettres (1922), p. 308-317 ; Claire Barat, "Voyageurs et perception des vestiges archéologiques à Sinope au temps de la représentation diplomatique française, sous le Consulat et l'Empire ", Anabases, 2 (2005), p. 163-175 ; Claire Barat, «La ville de Sinope, réflexions historiques et archéologiques », Sinope, The Results of Fifteen Years of Research, ed. T. K. Tezgör, Brill, Leiden, 2012, pp. 25-65.

20. H. Deherain, "Les premiers consuls de France sur la côte septentrionale de l'Anatolie ", Revue de l'histoire des colonies françaises, 17 (1924), p. 301-380. 
21. AMAEF, (Archives du ministère des Affaires étrangères français), Paris (La Courneuve), CCC, (Correspondance consulaire et commerciale) (1793-1901), Sinope.

22. AMAEF, CADN, (Centre des Archives diplomatiques de Nantes), Ambassade, Constantinople, Série D, Sinope.

23. "La situation politique et militaire de Sinope, (1807)", "Rapports de Fourcade sur sa conférence avec Taïar-Pacha (1804)», "sur la province d'Amasie ». AMAEF, Paris, Mémoires et Documents, Turquie, Tome 30.

24. Bu bilgi sadece Barat'ta yer almaktadır. Bkz. C. Barat, Voyageurs et perception des vestiges archéologiques, p. 166.

25. H. Deherain, a.g.m, p. 303-304; F. Cumont, a.g.m., p. 309.

26. Louis Allier 1795-1798 yılları arasında İstanbul'daki Fransız matbaasında müdürlük yapmış ve konsolos olarak tayin edilmeden önce Türkiye ve Mısır'da seyahatler yapmıştı. F. Bilici, La France et la mer Noire, p. 65.

27. AMAEF, Paris, CCC, Sinope, Nu. 10, Fourcade'dan Talleyrant'a, 1 Prairial An 12/21 Mayıs 1804. 28. H. Deherain, a.g.m, p. 315.

29. AMAEF, Paris, CCC, (1793-1901), Trébizonde, Tome I, 20 Vendémiaire An 12/13 Ekim 1803; Dupre'nin İstanbul'dan Trabzon'a yolculuğu hakkında bkz. Henri Cordier, « Voyage de Pierre Dupré de Constantinople à Trébizonde, 1803 ", Bulletin de la Section de Géographie, 32 (1917), p. 256-264.

30. H. Deherain Fourcade'ın Snop'a varışını 1803'ün yazı olarak nitelese de konsolosun raporlarından 9 Ekim 1803'te İstanbul'dan ayrıldığı anlaşılmaktadır. AMAEF, CADN, Constantinople, Ambassade, Série D, Correspondance avec les Échelles, Sinope, «Journal de mon voyage de Constantinople à Sinope ».

31. AMAEF, Paris, CCC, Sinope, Nu. 10, Fourcade'dan Talleyrant'a, 1 Prairial An 12/21 Mayıs 1804.

32. F. Bilici, La France et la mer Noire, p. 65-66.

33. F. Bilici, La France et la mer Noire, p. 58-59.

34. AMAEF, Paris, CCC, Trébizonde, Tome I, Dupre'den Talleyrant'a, 2 Nivose 12/24 Aralık 1803.

35. Şehrin nüfusunu 1500 kadar düşük veren başka kaynaklar da vardı. Dupré şehirde kale içinde Türklerin, kenar mahallelerde de Rumların meskun olduğu Sinop'ta sadece 3 Ermeni ailenin olduğunu ifade etmektedir. Bkz. Cordier, Voyage de Pierre Dupré de Constantinople à Trébizonde, p. 260.

36. Adrian Dupré, «Description de quelques villes et ports de la mer Noire ». Dupre'nin gezi notları için bkz. Chevalier Gamba, Voyage dans la Russie méridionale, Paris, 1826, p. 436-440.

37. J.M. Tancoigne, Lettres sur la Perse et la Turquie d'Asie, vol. II, Paris, 1819, p. 211.

38. AMAEF, CADN, Constantinople, Ambassade, Série D, Correspondance avec les Échelles, Sinope, Nu. 19, Fourcade'dan General Brune'e, 6 Germinal An 12 /27 Mart 1804.

39. 1831 Nüfus Sayımı'na göre Sinop Kazası'ndaki müslüman erkeklerin sayısı sadece 7,137'ydi. Buradan hareketle Sinop şehir merkezinin de yukarıdaki kaynakların da belirttiği gibi çok büyük bir nüfusu barındırmadığı tahmin edilebilir. Bkz. Enver Ziya Karal, Osmanlı İmparatorluğu'nda ilk Nüfus Sayımı-1831, T.C. Başbakanlık Devlet İstatistik Enstitüsü, Ankara 1995, s. 181 ; J.H. Kramers, Suraiya Faroqhi, "Sīnūb, Sinope", Encyclopaedia of Islam, Second Edition. Edited by P. Bearman, Th. Bianquis; C.E. Bosworth; E. van Donzel and W.P. Heinrichs. Brill, 2011.

40. AMAEF, CADN, Constantinople, Ambassade, Série D, Correspondance avec les Échelles, Sinope, Nu. 19, Fourcade'dan Brune'a, 6 Germinal An 12 /27 Mart 1804.

41. Fourcade Anadolu'da Gürcü Osman Paşa ile Tayyar Mahmud Paşa arasındaki çatışma nedeniyle karayolu yerine Sinop'a denizyolu ile gelmeyi tercih ettiğini belirtiyordu. AMAEF, Paris, CCC, Sinope, Nu. 16, Fourcade'dan Dişişlerine, 8 Brumaire An 13/30 Ekim 1804.

42. AMAEF, CADN, Constantinople, Ambassade, Série D, Correspondance avec les Échelles, Sinope, "Journal de mon voyage de Constantinople à Sinope ». 
43. AMAEF, Paris, CCC, Sinope, Nu. 10, Fourcade'dan Talleyrant'a, $1^{\text {er }}$ Prairial An $12 / 21$ Mayıs 1804.

44. AMAEF, Paris, CCC, Sinope, Nu. 16, Fourcade'dan Dişişlerine, Dupre'den Talleyrant'a, 8 Brumaire An 13/30 Ekim 1804.

45. Aynı Rapor.

46. AMAEF, CADN, Constantinople, Ambassade, Série D, Correspondance avec les Échelles, Sinope, «Observation sur la navigation de la mer Noire».

47. İbrahim Güler, “xvıII. Yüzyılda Sinop-Samsun İlişkilerine Ait Bazı Gözlemler”, Geçmişten Geleceğe Samsun, c. 1, Samsun Büyükşehir Belediyesi Yay., Samsun, 2006, s. 253-254; Selim Özcan, Tanzimat Döneminde Sinop'un Sosyal Ekonomik Durumu, Ondokuz Mayıs Üniversitesi Sosyal Bilimler Enstitüsü Yayınlanmamış Doktora Tezi, Samsun, 2007, s. 19-20.

48. A. Faivre d'Arcier, Les oubliés de la liberté, s. 64.

49. AMAEF, CADN, Constantinople, Ambassade, Série D, Correspondance avec les Échelles, Sinope, Nu. 3, Fourcade'dan General Brune'e, 24 Vendémiaire An 12/17 Ekim 1803.

50. AMAEF, CADN, Constantinople, Ambassade, Série D, Correspondance avec les Échelles, Sinope, Tome I, Fol. n¹5, Fourcade'dan General Brune'e, 26 Pluviose An 12/16 şubat 1804.

51. Fourcade daha sonraki yazışmalarında Sinop yarımadasının ortaya çıkardığı iki körfezin sadece doğuda yer alanının iyi bir demirleme olanağı sunduğunu; buna karşın batıda yer alanın ise buraya akan iki akarsudan dolayı demirlemeye pek uygun olmadığını yazmaktadır. 25 Kasım 1806 Paris, Nu: 58.

52. AMAEF, Paris, Mémoires et documents, (MD), Turquie, Tome 30, « De la Situation politique et militaire de Sinope ».

53. AMAEF, Paris, Mémoires et documents, (MD), Turquie, Tome 30 ; F. Bilici, La France et la mer Noire, s. 62-63.

54. AMAEF, CADN, Constantinople, Ambassade, Série D, Correspondance avec les Échelles, Sinope, Tome I, Nu. 5, Fourcade'dan General Brune'e, 14 Brumaire An 12/6 Kasım 1803; Aynı Dosya, Nu. 19, Fourcade'dan Brune'e 6 Germinal An 12 /27 Mart 1804.

55. AMAEF, CADN, Constantinople, Ambassade, Série D, Correspondance avec les Échelles, Sinope, Tome I, Fol. n³, Fourcade'dan General Brune'e, 24 Vendémiaire An 12/17 Ekim 1803.

56. AMAEF, CADN, Constantinople, Ambassade, Série D, Correspondance avec les Échelles, Sinope, Nu. 19, Fourcade'dan General Brune'e, 6 Germinal An 12 /27 Mart 1804.

57. Konsolos Fourcade bu döneme ilişkin kaygılarını "savaş halinde olan bir ülkede ticaret yapmaya" çalıştıklarını söyleyerek ortaya koymaktaydı. AMAEF, CADN, Constantinople, Ambassade, Série D, Correspondance avec les Échelles, Sinope, Nu. 28, Fourcade'dan General Brune'e, $5^{\mathrm{e}}$ jour complémentaire An 12/22 Eylül 1804.

58. Fourcade Fransa'nın Snop'a satacağı malları: değişik kalitede yünlüler, Marsilya ve Tunus tarzı kalpakları, pamuklu yünlüler, perdelik Rouen yünlüleri, silah kurşunları, hırdavat, kâğıt, çelik kasa ve kolonyal gıdalar; Sinop'tan alacağı malları da: İran ipeklileri, mazı, boraks, safran, zamk gibi ilaçlar, avignon buğdayı, garowe, ceviz ve keten yağı, az miktar balmumu, tavşan ve keçi derisi, Tokat bakırı ve kalitesi çok yüksek olan Kastamonu bakırı, Ünye şap madenleri, eğer ihraç etme yetkisi alınırsa orpiment, keten ve kenevir, Kereste ve inşaat kerestesi olarak vermektedir. AMAEF, CADN, Constantinople, Ambassade, Série D, Correspondance avec les Échelles, Sinope, Nu. 19, Fourcade'dan General Brune'e, 6 Germinal An 12 /27 Mart 1804.

59. Ne yazık ki Sinop'taki ticari potaniyeli anlamamı için çok önemli olan bu tablolar Paris ve Nantes'daki Sinop dosyalarında yer almamaktadır. AMAEF, CADN, Constantinople, Ambassade, Série D, Correspondance avec les Échelles, Sinope, Nu.19, Fourcade'dan General Brune'e, 6 Germinal An 12 /27 Mart 1804.

60. AMAEF, Paris, CCC, Sinope, Province, d'Amasie, ville \& territoire de Vezir Kioprou, 15 Nisan 1807. 
61. AMAEF, Paris, CCC, Sinope, Nu. 14, Fourcade'dan Dişişlerine, 15 şubat 1807.

62. AMAEF, Paris, CCC, Sinope, Nu. 30, Fourcade'dan Dişişlerine, 13 şubat 1807.

63. AMAEF, Paris, CCC, Sinope, Nu. 55 Bis, Fourcade'dan Dişişlerine, 2 Eylül 1806.

64. AMAEF, Paris, CCC, Sinope, «Situation Politique de l'Asie mineure », Fourcade'dan La Tour Maubourg'a, 1 Mayis 1808.

65. AMAEF, Paris, CCC, Sinope, Nu. 54, Fourcade'dan Dışişlerine, 2 Eylül 1806; İlginçtir ki İngiliz mallarına karşı Fransızların Anadolu'daki ticaretini geliştirilmesi için Anadolu piyasasının tanınması yönündeki tavsiyeler 19. Yüzyılın başlarında Fourcade tarafından yapıldı̆̆ı gibi yüzyılın sonlarında İngiliz, Alman Avusturya ve Belçika malları karşısında Fransa'nın daralan payına ilişkin olarak Trabzon Fransız konsolosu Cirière tarafından da yapılıyordu. Buradan Fransızların ticaret stratejilerinde, en azından Anadolu örneğinde çok büyük değişikliklerin olmadığı görülmektedir. AMAEF, Paris, CCC, Trébizonde, Tome 11,1894, Trabzon Ticaret Raporu. 66. AMAEF, Paris, CCC, Sinope, Nu. 20, Fourcade'dan La Tour Maubourg'a, 30 Temmuz 1808.

67. F. Bilici, La France et la mer Noire, s. 60.

68. Shaw, III. Selim, s. 379.

69. Canay şahin, The Rise and Fall of An Ayân Family in Eighteenth Century Anatolia: The Caniklizâdes (1737-1808), The Institute of Economics and Social Sciences of Bilkent University, Yayınlanmamış Doktora Tezi, Ankara, 2003, s. 67.

70. AMAEF, CADN, Constantinople, Ambassade, Série D, Correspondance avec les Échelles, Sinope, Fourcade'dan General Brune'e, 17 Frimaire An 13/8 Aralık 1804.

71. AMAEF, CADN, Constantinople, Ambassade, Série D, Correspondance avec les Échelles, Sinope, Nu. 20, Fourcade'dan General Brune'e, 10 Germinal An 2/31 Mart 1804.

72. Fourcade'ın Tayyar Mahmud Paşa'nın Rusya ile olan ilgisi hakkında şu değerlendirmeleri ilginçtir: "Rusyanın buralarda önemli bir etkinliği vardır. Bab-Ali paşayı korumaktadır; bunun nedeni sadece onunla mücadele edemeyeceği değil genel olarak paşanın bir Rus ajanı ve himayelisi olarak algılanmasından ileri gelmektedir. Paşa da Bab-1 Aliyi korumaktadır; zira Mahmud Paşa, Rusya'nın ne bağımsızlığını ne de Anadolu'da bir imparatorluk kurması desteklediğini bilmektedir. Ruslar, Tayyar Paşa'nın Osmanlı hükümetinin kolayca satabileceği şanından, cesaretinden, politikasından, yeteneğinden endişelenmektedir. Tayyar onları bir komşu olarak korkutmuş ve iyilik yapan biri olarak da güler yüz göstermiştir. Kırım topraklarından yıllık olarak 20,000 kuruşu feda edecek bir adam değildir." Aynı Belge; Diğer bir raporda da konsolos şu şekilde değerlendirmeler yapıyordu: “Tayyar Paşa bu milleti sevmediğini söylüyor. Onları çok kollamaktadır; buna hakkı vardır. Rus konsolosu beni temin etti ki bu topraklar ve memleketler Tayyar sayesinde Rusya'ya aittir ki Rusya her sene ona 20,000 kuruştan fazla vermektedir." AMAEF, CADN, Constantinople, Ambassade, Série D, Correspondance avec les Échelles, Sinope, Nu. 5, Fourcade'dan General Brune'e, 2 Brumaire An 12/25 Ekim 1803.

73. AMAEF, CADN, Constantinople, Ambassade, Série D, Correspondance avec les Échelles, Sinope, Nu. 20 Fourcade'dan General Brune'e, 10 Germinal An 2/31 Mart 1804.

74. Aynı Rapor.

75. Fourcade şubat 1805 tarihli raporunda Tayyar Paşa'ya olan bağımlılıklarını şu şekilde belirtiyordu: "Tayyar Paşa kendi eyaletinde olacak olan bir Fransız ticaretinin avantajlarını bilmektedir. O cesur, aktif ve zekidir. Hıristiyan Avrupalılara değer vermekte, onların değerlerini sevmektedir. Bizim buralar ile ilişkiler kurmamız için gerekli olan her şeye, halkın önyargısına ve sahilde yer alan küçük çapulcu ağaların tiranlığına karşı mücadele etmek için her şeye sahiptir. Bu taraflardaki anarşiyi bitirecek tek kişi odur. Tayyar Paşa'nın uzun zaman yaşamasını umacak ve onun dostluğundan istifade etmeye çalışacağım. Umarım bir güm yurttaşlarım bunun meyvelerini elde ederler". AMAEF, Paris, CCC, Sinope, Nu. 6, Fourcade'dan Dişişlerine, $1^{\mathrm{er}}$ Ventôse An 13/2 şubat 1805. 
76. AMAEF, CADN, Constantinople, Ambassade, Série D, Correspondance avec les Échelles, Sinope, Nu. 20, Fourcade'dan General Brune'e, 10 Germinal An 12/31 Mart 1804.

77. Fourcade, Çapanoğlu'ya yazdığı mektubun Fransa'nın, Çapanoğlu'nun idaresindeki bölgeler ile Karadeniz limanları vasıtası ile ticari ilişkiler kurmak, buralara mal alıp satmak ve nakletmek için bir teminat olduğunu; hakimiyeti altındaki bölgelerde malların taşınması ve alım satımını konusunda Çapanoğlu'nun dostluğuna ve adaletine güvendiğini ifade ediyordu. AMAEF, CADN, Constantinople, Ambassade, Série D, Correspondance avec les Échelles, Sinope, Tome I, Fol. Nu. 5, Fourcade'dan General Brune'e, 14 Brumaire An 12/6 Kasım 1803.

78. AMAEF, CADN, Constantinople, Ambassade, Série D, Correspondance avec les Échelles, Sinope, Nu. 13, Fourcade'dan General Brune'e, $1^{\text {er }}$ Pluviose An 12/22 Ocak 1804 ; H. Deherain, a.g.m, s. 320. 79. AMAEF, CADN, Constantinople, Ambassade, Série D, Correspondance avec les Échelles, Sinope, Nu. 28, Fourcade'dan General Brune'e 24 Thermidor An 12/12 Ağustos 1804.

80. Bu görüşme hakkında ayrıca bkz. AMAEF, Paris, Mémoires et documents (MD), Turquie, Tome 30, "Rapports de Fourcade sur sa conférence avec Taïar-Pacha (1804)". s. 344-349.

81. H. Deherain, Les premiers consuls, s. 321.

82. AMAEF, CADN, Constantinople, Ambassade, Série D, Correspondance avec les Échelles, Sinope, Nu. 29, Fourcade'dan General Brune'e, 2 Fructidor An 12/20 Ağustos 1804.

83. AMAEF, CADN, Constantinople, Ambassade, Série D, Correspondance avec les Échelles, Sinope, Nu. 32, Fourcade'dan General Brune'e, 14 Vendémiaire An 13/6 Ekim 1804.

84. AMAEF, CADN, Constantinople, Ambassade, Série D, Correspondance avec les Échelles, Sinope, Nu. 34, Fourcade'dan General Brune'e, 16 Vendémiaire An 13/8 Ekim 1804.

85. AMAEF, CADN, Constantinople, Ambassade, Série D, Correspondance avec les Échelles, Sinope, Nu. 32, Fourcade'dan General Brune'e, 14 Vendémiaire An 13/6 Ekim 1804.

86. AMAEF, Paris, CCC, Sinope, Nu. 16, Fourcade'dan Dişişlerine, 8 Brumaire An 13/30 Ekim 1804. 87. Aynı belge.

88. AMAEF, CADN, Constantinople, Ambassade, Série D, Correspondance avec les Échelles, Sinope, Nu. 19, Fourcade'dan General Brune'e, 6 Germinal An 12/27 Mart 1804.

89. AMAEF, CADN, Constantinople, Ambassade, Série D, Correspondance avec les Échelles, Sinope, Nu. 37, Fourcade'dan General Brune'e, 20 Brumaire An13/11 Kasım 1804.

90. Shaw kaynağını, bir süre Battal ve Tayyar Paşaların hizmetinde olan Pierlapier'nin, bu paşalara ilişkin olarak hazırladığı rapor olarak gösterdiği Sinop’taki bu gelişmeler hakkında maalesef Sinop'la ilgili olarak ne Nantes'da ne de Paris'teki arşivde belgeler yer almaktadır. Bu her iki tasnifte de Kasım 1804-şubat 1805 arasında bir kesinti dönemi göze çarpmaktadır. Shaw'ın raporu için bkz. AMAEF, Paris Correspondance Politique, Turquie, 210, 5 Thermidor An 13/24 Temmuz 1805.

91. İbrahim Serbestoğlu, “Trabzon valisi Canikli Tayyar Mahmud Paşa İsyani ve Caniklizâdelerin Sonu, 1805-1808," Uluslararası Karadeniz İncelemeleri Dergisi, 1 (2006), s. 95.

92. AMAEF, Paris, CCC, Sinope, Nu. 6, Fourcade'dan Dışişlerine, 12 Thermidor An 13/15 Temmuz 1805; Shaw, a.g.e., s. 378-382.

93. şahin, a.g.t, s. 75-76.

94. AMAEF, Paris, CCC, Sinope, Fourcade'dan Dışişlerine, 13 Fructidor An 13/31 Ağustos 1805.

95. AMAEF, CADN, Constantinople, Ambassade, Série D, Correspondance avec les Échelles, Sinope, Nu. 6, Fourcade'dan Ruffin'e, 15 şubat 1806; Aynı Dosya, Nu. 10, 12 Nisan 1806; AMAEF, Paris, CCC, Sinope, Nu. 47, Fourcade'dan Dişişlerine, 24 Mayıs 1806.

96. AMAEF, Paris, CCC, Sinope, Fourcade'dan Dişişlerine, 13 Fructidor An 13/31 Ağustos 1805.

97. AMAEF, CADN, Constantinople, Ambassade, Série D, Correspondance avec les Échelles, Sinope, Nu. 6, Fourcade'dan Ruffin'e, 6 Mayıs 1806.

98. AMAEF, CADN, Constantinople, Ambassade, Série D, Correspondance avec les Échelles, Sinope, Nu. 10, Extrait de mon Journal, Fourcade'dan Ruffin'e, 28, 29-30 Nisan 1806. 
99. I. Serbestoğlu, a.g.m., s. 99.

100. AMAEF, Paris, CCC, Sinope, Nu. 53, Fourcade'dan Dişişlerine, 5 Ağustos 1806.

101. AMAEF, CADN, Constantinople, Ambassade, Série D, Correspondance avec les Échelles, Sinope, «Extrait d'une lettre écrite au Ministre des Relations extérieures après la proscription de Tayar Mahmoud Pacha par M. Fourcade », 14 Thermidor An 13/2 Ağustos 1805.

102. Osman Köse, 1774 Küçük Kaynarca Antlaşması, TTK, Ankara, 2006, s. 114.

103. İlber Ortaylı, “XvıII. Yüzyıl Türk-Rus İlişkileri”, Osmanlı İmparatorluğu'nda İktisadi ve Sosyal Değişim, Makaleler, c. I, Turhan Kitabevi, Ankara, 2004, s. 385.

104. Osman Köse, "Balkanlarda Rus Konsolosluklarının Kuruluşu ve Faaliyetleri”, Turkish Studies/ Türkoloji Dergisi 1/2 (2006), s. 141-155; M. Tayyib Gökbilgin, “Konsolos”, İA, MEB, İstanbul 1985, s. 838 (836-840.); Ahmet Aksın, “Osmanlı-Rusya Ticari Münasebetleri (1787-1830)”, XIv. Türk Tarih Kongresi Bildirileri, c. II/II, Ankara 2005, s. 1031. (1027-1042)

105. Fourcade, Konuchenko'nun Eylül 1803 yılında Tayyar Paşa'yı Trabzon'da ziyaretine ilişkin olarak verdiği bilgilerde bu ziyaretin, Rus konsolosunun 18 aylık ikameti süresince gerçekleştirdiği ilk ziyaret olduğunu belirtmesi bize Rus konsolosunun yaklaşık olarak Mart 1802'de Sinop'taki görenine başladığını göstermektedir. AMAEF, CADN, Constantinople, Ambassade, Série D, Correspondance avec les Échelles, Sinope, Nu. 3, Fourcade'dan General Brune'e, 24 Vendémiaire An 12/17 Ekim 1803.

106. O. Köse, Küçük Kaynarca Antlaşması, s. 194-195; Fourcade 31 Mart 1804 tarihli raporunda da muhtemelen bu konuyu işaret ederek; Sinop'taki idarecilerin, Rus konsolosunun istediği tüm Şeyleri elde etmesi üzerine "hayretten donakaldıklarını" ve onunla ilişkilerini iyi tutmaya çalıştıklarını ifade ediyordu. Bkz. AMAEF, CADN, Constantinople, Ambassade, Série D, Correspondance avec les Échelles, Sinope, Nu. 20, Fourcade'dan General Brune'e, 10 Germinal An 12/31 Mart 1804.

107. AMAEF, CADN, Constantinople, Ambassade, Série D, Correspondance avec les Échelles, Sinope, Nu. 8, Fourcade'dan Ruffin'e, 28 Mart 1806.

108. AMAEF, Paris, MD, Turquie, Tome 30 , « De la Situation politique et militaire de Sinope ».

109. AMAEF, Paris, CCC, Sinope, Nu. 53, Fourcade'dan Dişişlerine, Nu. 60, 13 şubat 1807.

110. Fourcade'ın bu olumsuz değerlendirmelerine karşın Dupré, Sinop'a varışlarında adını Conochinco olarak verdiği Rus konsolosunun kendilerini gayet iyi karşıladığını yazmaktadır. Bkz. Cordier, Voyage de Pierre Dupré, s. 261-262.

111. AMAEF, Paris, CCC, Sinope, Nu. 16, Fourcade'dan Dişişlerine, 8 Brumaire An 13/30 Ekim 1804.

112. Aynı rapor.

113. Fourcade, Mısır Seferi'nde ele geçirilip Sinop'ta tutulan Fransızların serbest bırakılmaları konusunda da Rus konsolosunun paşa nezdindeki girişimlerinden dolayı onun için "dürüst bir adam" olarak niteliyordu. AMAEF, CADN, Constantinople, Ambassade, Série D, Correspondance avec les Échelles, Sinope, Nu. 5, Fourcade'dan General Brune'e, 2 Brumaire An 12/25 Ekim 1803.

114. AMAEF, Paris, MD, Turquie, Tome 30 , « De la Situation politique et militaire de Sinope ».

115. AMAEF, Paris, CCC, Sinope, Nu. 16, Fourcade'dan Dişişlerine, 8 Brumaire An 13/30 Ekim 1804.

116. AMAEF, CADN, Constantinople, Ambassade, Série D, Correspondance avec les Échelles, Sinope, Nu. 5, Fourcade'dan General Brune'e, 2 Brumaire An 12/25 Ekim 1803.

117. AMAEF, Paris, CCC, Sinope, Nu. 16, Fourcade'dan Dişişlerine, 8 Brumaire An 13/30 Ekim 1804.

118. AMAEF, Paris, CCC, Sinope, Nu. 48, Fourcade'dan Dişişlerine, 26 Mayıs 1806; AMAEF, CADN, Constantinople, Ambassade, Série D, Correspondance avec les Échelles, Sinope, Fourcade'dan Elçiliğe, $1^{\text {er }}$ Frimaire 14/22 Kasım 1805.

119. AMAEF, Paris, CCC, Sinope, Nu. 46, Fourcade'dan Dışişlerine, 10 Mart 1806. 
120. AMAEF, CADN, Constantinople, Ambassade, Série D, Correspondance avec les Échelles, Sinope, Nu. 3, Fourcade'dan General Brune'e, 24 Vendémiaire An 12/17 Ekim 1803; Aynı dosya, Nu. 21, Fourcade'dan Brune'e, 14 Germinal An 12/4 Nisan 1804; Aynı dosya, Nu. 5, Fourcade'dan Brune'e, 2 Brumaire An 12/25 Ekim 1803.

121. AMAEF, CADN, Constantinople, Ambassade, Série D, Correspondance avec les Échelles, Sinope, Nu. 10, Fourcade'dan Ruffin'e, 12 Nisan 1806; AMAEF, Paris, CCC, Sinope, Nu. 16, Fourcade'dan Dışişlerine, 8 Brumaire An 13/30 Ekim 1804.

122. AMAEF, Paris, CCC, Sinope, Nu. 46, Bernage'dan Dişişlerine, 11 şubat 1806.

123. AMAEF, CADN, Constantinople, Ambassade, Série D, Correspondance avec les Échelles, Sinope, Nu. 2, Fourcade'dan Ruffin'e, 5 Eylül 1806.

124. AMAEF, CADN, Constantinople, Ambassade, Série D, Correspondance avec les Échelles, Sinope, Nu. 3, Fourcade'dan General Brune'e, 24 Vendémiaire An 12/17 Ekim 1803.

125. AMAEF, CADN, Constantinople, Ambassade, Série D, Correspondance avec les Échelles, Sinope, Nu. 10, Fourcade'dan Ruffin'e, 3 Ocak 1806; Rus konsolosu 26 Mart'ta Sinop'a döndü. 12 gün kaldığı Erzurum'da bir kaç gün Yusuf Paşa ile de görüşmüş; Ahıska'daki Rus askeri yetklilerinden beklediği mektuplar gelinde de Trabzon'a buradan da Sinop'a dönmüştü. Bkz. Aynı Dosya, Fourcade'den Ruffin'e, 29 Mart 1806.

126. Akçura, Dağılma Devri, s. 118-120.

127. Shaw, III. Selim, s. 481-485.

128. Fourcade, Rus meslektaşının şehirden ayrılması hakkında "Konuchenko Sinop'tan ayrıldı. Sağ salim gideceğinden şüpheliyim. Kadı, Rus konsolosundan daha önce kendisine başvurmadığı ve Sinop'u kendi isteği ve arzusu ile terk ettiğini belirten bir yazı istedi. Ailesini ve eşyalarını korumak gerektiği için Rus konsolosu kendinden istenilen her şeyi imzaladı". AMAEF, Paris, CCC, Sinope, Nu. 46, Fourcade'dan Dişişlerine, 13 şubat 1807.

129. AMAEF, Paris, CCC, Sinope, Nu. 46, Fourcade'dan Dişişlerine, 13 şubat 1807.

130. Özcan'ın Sinop'taki Rus konsolosluğuna dair şu bilgileri verir:"Sinop'taki Rus konsolosluğu yıkılmış ve konsolos şehri gemiyle terk etmek zorunda kalmıştır”. Bkz. Özcan, Tanzimat Döneminde Sinop, s. 15; Fakat Fransız kaynaklarında benzer bilgiler yer almaz. Sadece Fourcade 22 Ocak 1804 tarihli raporunda Sinop'taki kâhya ile Rus konsolosu arasında bir anlaşmazlık çıktığını ve 15 günlük bir münakaşa döneminden sonra Konuchenco'nun yatıştığını ifade ediyordu. AMAEF, CADN, Constantinople, Ambassade, Série D, Correspondance avec les Échelles, Sinope, Nu. 13, Fourcade'dan Brune'e, $1^{\text {er }}$ Pluviôse An 12/22 Ocak 1804 ; Osmanlı arşiv belgelerine göre Sinop Ayanı Gözübüyükoğlu Rus konsolosunu Sinop'tan kovmuştu. Bu konuda Tayyar Paşa'ya gönderilen hükümlerde konsolosun görevine iadesi ve Gözübüyükoğlu'nun da gerekli cezayı alması gerektiği ifade ediliyordu. Bu konuda bkz. BOA. HAT. 224/12490/B, 19 N 1218/2 Ocak 1804; BOA. HAT. 224/1290, 29 Z 1218/10 Nisan 1804; BOA. C. HR. 36/1786, 29 L 1218/11 şubat 1804.

131. H. Deherain, Les premiers consuls, s. 323.

132. AMAEF, CADN, Constantinople, Ambassade, Série D, Correspondance avec les Échelles, Sinope, Nu. 1, Fourcade'dan Elçiliğe, 17 Vendémiaire An 14/9 Ekim 1805.

133. Bu raporun tarihi her ne kadar 12 şubat 1807 olsa da, Fourcade'ın bunu Sinop'un idari durumunu gösteren bir örnek bir olay olarak vermesi diğer yazışmalarda da görüldüğü gibi Kastamonu müteselliminin Sinop'a 1806'nın sonlarında geldiğini göstermektedir. AMAEF, Paris, MD, Turquie, Tome 30, « De la Situation politique et militaire de Sinope ».

134. AMAEF, CADN, Constantinople, Ambassade, Série D, Correspondance avec les Échelles, Sinope, Fourcade'dan Elçiliğe, ${ }^{\text {er }}$ Frimaire 14/22 Kasım 1805.

135. AMAEF, CADN, Constantinople, Ambassade, Série D, Correspondance avec les Échelles, Sinope, Nu. 5, Fourcade'dan Ruffin'e, 3 şubat 1806. 
136. Fourcade'ın Kastamonu mütesellimi ile iyi ilişkiler kurduğu anlaşılmaktadır. Zira konsolos 20 Ocak 1806 tarihli raporunda mütesellimin birçok defa kendisini Kastamonu'ya davet ettiğini; fakat Anadolu'daki karışıklıklar ve Tayyar Paşa ile olan ilişkilerine zarar vermemek için bu seyahati ertelediğini ifade ediyordu. AMAEF, Paris, CCC, Sinope, Nu. 44, Fourcade'dan Dışişlerine, 20 Ocak 1806.

137. Fakat elçilikten gelen genelgelerde Fourcade'ın bu derebeyleri ile olan ilişkilerinde dikkatli olması gerektiği belirtiliyordu. AMAEF, CADN, Constantinople, Ambassade, Série D, Correspondance avec les Échelles, Sinope, Elçilikten Fourcade'a, 12 Mart 1806.

138. AMAEF, CADN, Constantinople, Ambassade, Série D, Correspondance avec les Échelles, Sinope, Nu. 5, Fourcade'dan Ruffin'e, 3 şubat 1806.

139. AMAEF, Paris, CCC, Sinope, Nu. 6, Fourcade'dan Dişişlerine, 15 şubat 1806; AMAEF, CADN, Constantinople, Ambassade, Série D, Correspondance avec les Échelles, Sinope, Nu.6, Fourcade'dan Ruffin'e, 15 şubat 1806; H. Deherain, Les premiers consuls, s. 324.

140. H. Deherain, Malte-Brun'un Annales de Voyages, Tome XIII, 1811s. 408'de bu rapor(mémoire)dan bahsetmesine rağmen şimdiye kadar bu raporun ortaya çıkmadığını belirtmektedir. Bkz. H. Deherain, Les premiers consuls, s. 325.

141. AMAEF, Paris, CCC, Sinope, Nu. 46, Bernage'dan Dişişlerine, 11 şubat 1806.

142. AMAEF, CADN, Constantinople, Ambassade, Série D, Correspondance avec les Échelles, Sinope, Nu. 8, Fourcade'dan Ruffin'e, 28 Mart 1806.

143. Fransız Dışişleri'nden Fourcade'a gelen genelgeye göre, hükümetin kendisi için bir şansölye atamadığını; bu görevi yapabilecek biri konusunda seçimin Fourcade'da olduğunu ifade ediyordu. AMAEF, Paris, CCC, Sinope, Dişişlerinden Fourcade'a, 7 Vendémiaire An 10/30 Eylül 1803; Nitekim Fourcade aradığı bu görevliyi İstanbul'daki ikâmeti sırasında bulacaktı. 1777'de Dışişleri bünyesine dâhil olan Bernage, Marsilyalı bir ticarethanenin temsilcisi olarak Rusya'nın Karadeniz limanlarında ticari gezilerde bulunmuştu. Fourcade, İstanbul'da tanıdığı Bernage'a şansölyelik görevini teklif etmişti. Bkz. H. Deherain, Les premiers consuls, s. 361-362.

144. AMAEF, CADN, Constantinople, Ambassade, Série D, Correspondance avec les Échelles, Sinope, Nu. 8, Fourcade'dan Ruffin'e, 28 Mart 1806.

145. AMAEF, Paris, CCC, Sinope, Nu. 6, Fourcade'dan Dişişlerine, 15 şubat 1806.

146. İlerde Orta ve Doğu Karadeniz Bölgesi'nin, Canikli ailesinden sonra hâkimi haline gelecek olan Hazinedaroğlu ailesinin kurucusu olan Süleyman Ağa'nın bu ilk dönemleri için bkz. Mehmet Beşirli, “XIx. Yüzyılın Başlarında Karadeniz Bölgesi ve Âyan-Devlet Perspektifinden Trabzon Valisi Hazinedârzâde Süleyman Paşa", Trabzon ve Çevresi Uluslararası Tarih-Dil-Edebiyat Sempozyumu Bildirileri, 03-05 Mayıs 2001, c. I, Trabzon Valiliği Yayınları, Trabzon, 2002, s. 328-330.

147. AMAEF, CADN, Constantinople, Ambassade, Série D, Correspondance avec les Échelles, Sinope, Nu. 10, « Extrait de mon Journal », Fourcade'dan Ruffin'e, 12 Nisan 1806.

148. AMAEF, CADN, Constantinople, Ambassade, Série D, Correspondance avec les Échelles, Sinope, Nu. 6, 6 Mayıs 1806.

149. AMAEF, Paris, CCC, Sinope, Nu. 46, Bernage'dan Dişişlerine, 11 şubat 1806.

150. Konsolosun özellikle Canik'teki gelişmeleri yakından takip ettiği ve bu konudaki günlük gelişmeleri elçiliğe gönderdiği görülmektedir. Bkz. "Bulletin de la Province de Djanick" AMAEF, CADN, Constantinople, Ambassade, Série D, Correspondance avec les Échelles, Sinope, 28 Temmuz-3 Ağustos 1806.

151. H. Deherain, Les premiers consuls, s. 354; AMAEF, CADN, Constantinople, Ambassade, Série D, Correspondance avec les Échelles, Sinope, 1 Ağustos 1806.

152. Fourcade Hanya'daki esaretinden beri ciddi sağlık sorunları yaşıyordu ve Sinop'taki konsolosluk süresince de bu rahatsızlığına sıtma, mide rahatsızlığı ve bazı fiziksel rahatsızlıklar da eklenmişti. Bkz. F. Cumont, Pascal Fourcade, s. 309. 
153. Fourcade sağlık sorunları nedeniyle, bir dönem Tayyar Paşa'nın da doktorluğunu yapan Bozari'ni tavsiyesiyle kendisine daha iyi geleceğine inandığı Havza'daki kaplıcalara gitmek istediğini belirtiyordu. AMAEF, Paris, CCC, Sinope, Nu. 53, Fourcade'dan Dişişlerine, 5 Ağustos 1806; H. Deherain, Les premiers consuls, s. 326.

154. C. Barat, Voyageurs et perception des vestiges archéologiques à Sinope, s. 167; H Deherain, Les premiers consuls, s. 326-337.

155. AMAEF, Paris, CCC, Sinope, Nu. 54, Fourcade'dan Dişişlerine, 15 Ekim 1806.

156. Ne yazık Osmanlı-İngiliz-Rus Savaşı'nın yaşandığı bu dönemde Sinop’taki gelişmeler hakkında Fourcade'ın herhangi bir raporuna rastlayamıyoruz. Hâlbuki bu dönemde Fransız Elçisi Sebastiani, İngiliz donaması İstanbul'u tehdit ettiğinde Sinop'a Fransız mühendisler göndererek Sinop Yarımadası'nın her iki tarafını gören ve limanı koruyan yüksek bir tepeye bir batarya kurdurmuş ve bunun gibi şehrin savunması için başka çalışmalar yaptırmıştı. Bkz. Démosthène Baltazzi, « Notice sur Synope », Revue de l'orient de l'Algérie et des Colonies, Paris, 1854, s. 8-11.

157. AMAEF, Paris, CCC, Sinope, Bernage'dan Dışişlerine, 26 Aralık 1807.

158. AMAEF, CADN, Constantinople, Ambassade, Série D, Correspondance avec les Échelles, Sinope, Nu. 26, Fourcade'dan Sebastiani'ye, 22 Mart 1808.

159. AMAEF, CADN, Constantinople, Ambassade, Série D, Correspondance avec les Échelles, Sinope, Nu. 13, Fourcade'dan de Latour-Maubourg'a, 13 Ocak 1808.

160. AMAEF, Paris, CCC, Sinope, Fourcade'dan Dışişlerine, "Situation Politique de l'Asie mineure ", 1 Mayıs 1808.

161. F. Cumont, Pascal Fourcade, s. 313.

162. Bu durumu Paris ve Nantes'taki Sinop dosyalarından da anlamak mümkündür. Dışişlerinin Ticari İşler bürosundan gelen 30 Brumaire An 13/21 Kasım 1804 tarihli genelgede Fourcade'ın 1 Thermidor An 11/20 Temmuz 1803 tarihinden itibaren büro ile yazışmadığını ve bu konuda uzun bir zaman geçirdiğinden bahsetmekteydi. Gelen genelgede Trabzon'da Dupré ve Ereğili'de Allier'nin Dışişleri ile yazıştığı belirtilerek büro ile yazışmayan tek görevlinin Fourcade olduğundan bahsediliyordu. Demek ki konsolosluğun ilk dönemleri hakkında Paris'teki tasniflerde çok az belgenin olması ve bunların büyük oranda Nantes'daki tasniflerde yer alması Fourcade'ın yazışmalarının elçilikte tutulduğunu ve Fourcade'ın faaliyetlerine ilişkin olarak çok az belgenin Paris'e iletildiği göstermektedir. AMAEF, Paris, CCC, Sinope, Dişişlerinden Fourcade'a, 30 Brumaire An 13/21Kasım 1804; F. Cumont, Pascal Fourcade, s. 313.

163. H. Deherain, Les premiers consuls, s. 351-352.

164. AMAEF, Paris, CCC, Sinope, Nu. 56, Fourcade'dan Dişişlerine, 2 Eylül 1806.

165. AMAEF, Paris, CCC, Sinope, Nu. 14, Fourcade'dan Dişişlerine, 15 Nisan 1807.

166. C. Barat, Voyageurs et perception des vestiges archéologiques à Sinope, s. 167.

167. Bu rapor Annales des Voyages'da yayınlandı. Bkz. Pascal Fourcade, "Mémoire sur Pompeiopolis ou Tasch-Kouprou avec quelques remarques sur Tovata ou Voyavat lu à la troisième classe de l'Institut ", Annales des voyages, de la géographie et de l'histoire, 14 (1811), s. 30-58.

168. Bu rapor hakkında bazı eserlerde kısa değerlendirmeler olsa da şu ana kadar bu rapora ulaşılmış değildir. Bkz. H. Deherain, Les premiers consuls, s. 325.

169. "Quelques observations sur la Carte d'une partie du Pont Galatique et de la Paplagonie ». AMAEF, Paris, CCC, Sinope, Nu. 58; AMAEF, CADN, Constantinople, Ambassade, Série D, Correspondance avec les Échelles, Sinope, Fourcade'dan Ruffin'e, 3 şubat 1806; Harita için bkz. «Carte d'une Partie du Pont Galatique de la Paphlagonie Par M. Fourcade aîné, Commissaire Général des Relations Commerciales de France et Consul Général de S. M. Impériale Napoléon à Sinope ».

170. "Ville et territoire de Vezir-Kioprou », "Ville et territoire de Ladick », AMAEF, Paris, CCC, Sinope. 
171. «Province d'Amasie, de l'administration civile et militaire », « Amasie, Esprit public, mœurs, caractère", "Suite de la description de la province d'Amasie", "Province d'Amasie, Commerce ", "Bains et pays de Kavza, Thermes" başlıklarını taşıyan bu raporlar için bkz. AMAEF, Paris, MD, Tome 30, s. 376-406.

172. AMAEF, CADN, Constantinople, Ambassade, Série D, Correspondance avec les Échelles, Sinope, Nu. 15, Fourcade'dan General Brune'e, 26 Pluviose An 12/16 şubat 1804.

173. Sinop'un antik geçmişi üzerine sadece Paris'teki tasnifte, «Plans des bains du gimnase de l'ancienne Sinope levé en pluviôse de l'an 12 par J.-C. Escalon » ve "Citernes antiques, réservoirs d'eau pour le Gymnase de Sinope » adlı iki plan yer almaktadır. Bkz. AMAEF, Paris, CCC, Sinope; "La situation politique et militaire de Sinope, (1807) », AMAEF, Paris, MD, Tome 30 ; C. Barat, Voyageurs et perception des vestiges archéologiques à Sinope, s. 168; H. Deherain, Les premiers consuls, s. 341-345.

174. 22 Mart 1808, CADN, No 26.Sebastiani'ye

175. Konsolosluk tercümanı olarak Fourcade, Hanya'dan itibaren yanında olan Fransız asıllı Simian'ı seçmişti. Fourcade, Devrim döneminde bir İsveçli bir mühendisin yanında yer alan Simian'ı kendisine katılmaya davet etmiş ve Hanya'daki konsolosluğunda da beraber çalışmışlardı. AMAEF, Paris, CCC, Sinope, Nu. 4, Fourcade'dan Taleyrand'a, $1^{\text {er }}$ Thermidor An 11/20 Temmuz 1803; 18 Germinal An 11/8 Nisan 1803 tarihli mektubunda Fourcade elçiliğe konsolosluğun tercümanı olarak Simian'ı seçtiğini belirtmekte ve Halep ve Selanik konsolosluklarında olduğu gibi Simian'a da 4,000 frank maaş talep etmekteydi. Simian'ın dil oğlanı olarak ve bir kaç seneden beri de Rodos'taki tersanede İsveçli mühendislerin tercümanıydı ve Türkçeyi hem yazma hem de konuşmada iyi kullanan bir Fransız'dı. AMAEF, CADN, Constantinople, Ambassade, Série D, Correspondance avec les Échelles, Sinope Nu.1, Fourcade'dan Brune'a, 18 Germinal An 11/8 Nisan 1803.

176. AMAEF, Paris, CCC, Sinope, Fourcade'dan Latour-Maubourg'a, 17 şubat 1809.

177. AMAEF, Paris, CCC, Sinope, Fourcade'dan Latour-Maubourg'a, 24 şubat 1809.

178. H. Deherain, Les premiers consuls, s. 363-367.

179. F. Bilici, «La France et la mer Noire sous la Restauration », Enjeux Politiques, économiques et Militaires en mer Noire ( $\mathrm{xv}^{\mathrm{e}}-\mathrm{XxI}^{\mathrm{e}}$ siècles), dir. F. Bilici, I. Candea, A. Popescu, Éditions Istaros, Braila 2007, s. 655-676.

\section{RÉSUMÉS}

Fransız Devrimi ve sonrasında Mısır'ın işgali, Osmanlı-Fransız ilişkilerinde bir kriz dönemi oluşturmakla birlikte; Fransızların 17. ve 18. yüzyıl boyunca Karadeniz'de ticaret yapma yönündeki girişimlerinin de durmasına neden oldu. Fakat 25 Temmuz 1802 yılında yapılan Paris Antlaşması Osmanlı-Fransız ilişkilerinde yeni bir yumuşama dönemi başlattı. Paris Antlaşması'yla Karadeniz'de ticaret yapma hakkı Fransızlara da verildi. Bu şekilde Fransa daha önce sahip olduğu imtiyazlara bu kez de Karadeniz'i de ekleyerek antlaşmanın 2. ve 3. maddeleriyle Fransa Karadeniz'in değișik noktalarına konsolosluklar kurma hakkı elde etti. Bu bağlamda 21 Eylül 1802 yılında çıkan bir karar ile Sinop'ta genel bir konsolosluk (komiserlik) ve buna bağlı olarak Trabzon ve Ereğli'de birer alt komiserlik kuruldu. Sinop'a konsolos olarak atanan Pascal Fourcade 1803 Ekim'inde Sinop'taki konsolosluk görevine başladı. Fourcade Sinop'ta iyi bir şekilde karşılandı. Fakat 1805 yılında Tayyar Paşa'nın sürgüne gönderilmesiyle 
birlikte Fourcade'ın tüm planları alt üst oldu. Bunun yanında Fourcade'ın konsolosluğunun başarılı olmasının önündeki diğer bir engel de şehirdeki Rus meslektaşı Konuchenco'nun tutumuydu. 1806 Osmanlı-Rus Savaşı sonrasında Konuchenko Sinop'tan çıkarılsa da Tayyar Mahmud Paşa sonrasında Anadolu'ya hâkim olan kargaşa ortamı Fourcade'ın ticari projelerini gerçekleştirmekten alıkoydu. Bunun yanında Osmanlı-Fransız ilişkilerindeki dalgalanmalar da Fourcade'ı Sinop'ta zor durumda birakan diğer bir engeldi. Her ne kadar Fourcade Sinop'ta Fransız ticaretini geliştirme yönünde başarılı olmasa da altı yıllık konsolosluğunun geride bırakmış olduğu kaynaklar Sinop ve çevresinin tarihi, arkeolojisi, coğrafyası ve 19. yüzyılın başlarındaki iktisadi ve siyasi durumu yansıtması açısından araştırmacılara önemli bir kaynak sağlamaktadır. Bu bakımdan bu çalışma da Fransız dışişleri bakanlığı arşivlerinde yer alan belgelerden hareketle Fourcade'ın konsolosluğunu değerlendirme amacındadır.

The French Revolution and the invasion of Egypt created a crisis period in Ottoman-French relations and also arrested the French initiatives to trade in the Black Sea from the 17th century. However, on 25 July 1802 with the Treaty of Paris, the French were also given the right to trade in the Black Sea. In this way, France added the Black Sea to his privileges. With the 2nd and 3rd articles of the treaty, France has obtained the right to create consular agents on various points of the Black Sea. In this context, by a decision of 21 September 1802, a general consulate in Sinop and two consular agents in Trabzon and Ereğli, depended to consulate general of Sinop, established. Pascal Fourcade was appointed as consul to Sinop and arrived to the city in the October of 1803. Fourcade was welcomed in a good way in Sinop; but the anarchy reigned in Anatolia after the Tayyar Pasha's exile, and intrigues of Russian colleague, Konuchenco, Fourcade stayed in difficult situations in the city.

In fact, the preference of Sinop, as a general consulate centre was not in accordance with the terms of the period. Although Sinop had one of the best ports of the Southern Black Sea, the city was not as active as in the past on a commercial basis. It is known that Sinop was one of the places that mostly affected by Ottoman-Russian wars. Sinop had profited commercial relation that took place between the north-south ports of the Black Sea under the Ottoman dominance over the Black Sea. Especially in trade with Crimea, Sinop was the main port for Anatolian products. However, ever-expanding dominance of the Russia over the Black Sea, not only affected commercial relations between Black Sea ports but also started a decline period for southern Black Sea ports as Sinop and Trabzon that had strong commercial affairs with northern Black Sea. In this state Sinop was a small coastal town in the beginning of 19th century. But as the French consul stated, Sinop would became a strategic position as a port for trade of Anatolia and Iran in case of favourable conditions.

Fourcade had very high expectations for the future of the city. The most important task of French consul was to achieve new markets for French goods; receive raw materials coming from Iran and Anatolia and establish warehouses for goods in Sinop. In this regard, Fourcade was describing the city as a trading port that had a very bright future and comparing the city to Alexandria and Baghdad, and also trying to show that Sinop was better port than Samsun and Trabzon.

Fourcade's these expectations were not only connected to the creation of favourable conditions for trade and establishment of the necessary infrastructure. In fact, the realization of these plans depended on Tayyar Pasha's power, the governor of southern Black Sea region. As Fourcade's words, the main purpose of the consul was to establish good relations with Tayyar Paşa and convince him to gains of future French trade in his region. In the spring of 1804, Fourcade met with Tayyar Pasha and achieved positive results for his future plans; but because of obstructions of Russian consul in Sinop Fourcade did not realize his plans that emerged after the consul and Tayyar Paşa's interview in Bafra. Moreover defeat of Tayyar Pasha by Yusuf Pasha and exile to Sohum in 1805 created a real period of solitude for Fourcade in Sinop. 
Fourcade was met in early days in Sinop with Russian jealousy. When he arrived to Sinop, the city had been hosting Russian consuls since 1785. So, the biggest obstacle to plans of French consul was the Russian colleague Konuchenco. As the agent of Russia who did not want another European power in Black Sea, Konuchenco showed all his effort to fail Fourcade's mission in Sinop. In this context it is difficult to say that French Foreign Ministry predicted Russian rivalry in the Black Sea ports. Whereas with the Treaty of Küçük Kaynarca, Russian had gained to right to trade in Black Sea and soon after the treaty they established a consular network in the port cities. Sinop was one the port cities that the Russian preferred to create a consular agent. Russian consuls in Sinop were so powerful that they could change kadı of Sinop. There were also very strong relations between Russian consul Konuchenco and Tayyar Paşa who had territories in Crimea consigned to Battal Hüseyin Paşa, father of Tayyar Paşa, in his exile in Russia. In the first two years of consulate, Fourcade complained so often the relations between Tayyar Paşa and Konuchenco and Russian dominance over the Sublime Porte that seen in Sinop. Indeed, until the expulsion of Russian consul in February 1807, a diplomatic war had taken place in Sinop. Both consuls followed each other tightly and try to stop each other's activities. In this way, in the early years of the 19th century Sinop lived a provincial diplomacy period that created by presence of French and Russian consuls in the city.

After the Tayyar Pasha's exile to Sohum, all the balance in Anatolia had changed. In the period of Tayyar Paşa's reign in the region, Fourcade had only to try to establish good relation with Tayyar Paşa for French trade; but after 1805, Fourcade rested between a multiple powers in Sinop. In this state the turmoil reigned in Anatolia after the Tayyar Pasha's exile was a real obstacle for Fourcade's plans. Furthermore the consulate was attacked by Greek sailor under the Russian protection in 1806 when Fourcade was in Kastamonu. But aggression of 1807 was more drastic for French consulate in Sinop. Fourcade and chancellor of consulate, Bernage, were injured by Laz sailors who participated the turmoil ended Selim III' reign, debarked in Sinop in way of their homeland. The expulsion of Russian consul Konuchenco from Sinop by Ottoman-Russian War broke out in 1806 was really created a liberty atmosphere in the city. But Russian-French rapprochement and the Treaty of Tilsit reversed this atmosphere against to French in Anatolia. These new conditions that clearly seen in aggression of 1807 , showed also the future of the Fourcade's mission in Sinop.

Although Fourcade's Sinop consulate did not obtain significant result for French trade; his sixyear consulate left us very valuable documents that exist in French foreign ministry archives in Paris and Nantes. These consular reports and detailed travel voyages accounts are very valuable sources for Southern Black Sea region at beginning of the $19^{\text {th }}$ century. Fourcade, like an archaeologist and geographer travelled in his consular district and prepared detailed reports on Sinop, Kastamonu, Ladik and Amasya region. A portion of them were published; but there are also some reports are not reached until now. It is the Fourcade's archaeological activities that make the Sinop consulate worthwhile in the world of science. But beyond this, archival sources on Fourcade's six-year consulate, gives us valuable information about on the situation of Anatolia in Age of Ayans at the beginning of the 19th century, Russian impact on the Black Sea and history of Ottoman-French relations in the Black sea. This study aims to make a review on Fourcade's Sinop consulate by using resources of the French archives.

La Révolution française et l'invasion de l'Égypte qui suivit, ont créé une période de crise dans les relations franco-ottomanes et également ont mis un coup d'arrêt aux initiatives françaises, suivies depuis le XVII ${ }^{e}$ siècle, pour commercer en mer Noire. Cependant, avec le Traité de Paris (25 juillet 1802), les Français ont reçu le droit de commercer dans cette mer, ajoutant ainsi la mer Noire à leurs privilèges. Par les articles 2 et 3 du traité, la France a obtenu le droit de créer des agents consulaires en divers points de la mer Noire. Dans ce contexte, par une décision du 21 septembre 1802, le gouvernement français a établi un consulat général (commissaire général) 
à Sinop et deux agents consulaires (sous-commissaires) à Trabzon et à Ereğli, dépendant du consulat général de Sinop. Pascal Fourcade a été nommé consul de Sinop et est arrivé dans la ville en octobre 1803 ; il a été bien accueilli, mais en raison de l'anarchie causée par l'exil de Tayyar Pacha en Anatolie et des intrigues de son collègue russe, Konuchenco, il s'est trouvé en position difficile dans la ville.

En fait, le choix de Sinop comme centre général d'un consulat n'était pas excellent vu les conditions de la période. Bien qu'ayant l'un des meilleurs ports de la côte méridionale de la mer Noire, la ville n'était pas aussi active que par le passé, sur le plan commercial. On sait que Sinop a été l'un des endroits que les plus touchés par la guerre russo-turque. Elle avait profité des relations commerciales entre les ports méridionaux et septentrionaux de la mer Noire sous domination ottomane, et surtout, dans les échanges avec la Crimée, Sinop était le principal port pour les produits anatoliens. Toutefois, l'expansion de la Russie en mer Noire a affecté les relations commerciales entre les ports de cette mer Noire et aussi initié une période de déclin pour les ports méridionaux, comme sinop et Trabzon, qui avaient d'importants échanges commerciaux avec les ports septentrionaux. Ainsi, Sinop n'était-elle qu'une petite ville côtière au début du XIX ${ }^{\mathrm{e}}$ siècle. Mais, comme le consul français l'a déclaré, elle aurait pu devenir, dans des conditions favorables, une position stratégique comme port pour le commerce avec l'Anatolie et l'Iran.

Fourcade mettait des espoirs très élevés dans l'avenir de cette ville. La tâche la plus importante du consul français était d'atteindre de nouveaux marchés pour les marchandises françaises, de recevoir des matières premières en provenance d'Iran et d'Anatolie et d'établir des entrepôts de marchandises à Sinop. Fourcade décrivait la ville comme un port de commerce avec un brillant avenir, la comparait à Alexandrie et à Bagdad, et essayait également de prouver qu'elle était un meilleur port que Samsun et Trabzon.

Les attentes de Fourcade n'étaient pas seulement liées à la création de conditions favorables pour le commerce et à l'établissement des infrastructures nécessaires. En fait, la réalisation de ses plans dépendait de la puissance de Tayyar Pasha, qui était gouverneur de région, de Sinop à Trébizonde. Le but principal du consul était d'établir de bonnes relations avec Tayyar Pașa et de le convaincre des gains qu'apporterait à sa région le futur commerce des Français. Au printemps 1804, Fourcade a rencontré Tayyar Pacha et obtenu des résultats positifs pour ses projets ; mais en raison de l'obstruction du consul de Russie à Sinop, il n'a pas réalisé les plans dressés après l'entrevue du consul et de Tayyar Pacha, à Bâfra. Par ailleurs, la défaite de Tayyar Pacha devant Yusuf Pacha et son exil à Sohum en 1805 ont entraîné pour Fourcade une véritable " période de solitude » à Sinop.

Fourcade a dû faire face dès ses premiers jours à Sinop à la jalousie russe. Quand il est arrivé à Sinop, la ville était l'hôte de consuls russes depuis 1785 . Donc, le plus grand obstacle aux plans du consul français a été son collègue russe, Konuchenco. En tant qu'agent de la Russie qui ne voulait pas d'une autre puissance européenne en mer Noire, Konuchenco a mis tous ses efforts à faire échouer la mission de Fourcade à Sinop. Dans ce contexte, il est difficile de dire que le ministère des Affaires étrangères français avait prévu la rivalité russe dans les ports de la mer Noire. Alors qu'avec le traité de Küçük Kaynarca, la Russie avait gagné le droit de commercer en mer Noire et, peu de temps après le traité, établi un réseau consulaire dans les villes portuaires. Sinop était l'une des villes portuaires préférées par les Russes pour établir un agent consulaire. Les consuls russes à Sinop étaient si puissants qu'ils pouvaient faire changer le kadi. Il y avait également des relations très fortes entre le consul russe Konuchenco et Tayyar Pașa qui avait des possessions en Crimée, attribuées à Battal Hüseyin Pacha, le père de Tayyar Pacha, lors de son exil en Russie. Au cours des deux premières années de son consulat, Fourcade se plaint souvent des relations entre Tayyar Pacha et Konuchenco et de la domination russe sur la Sublime Porte. Jusqu'à l'expulsion du consul de Russie en février 1807, une " guerre diplomatique » a lieu à Sinop : les deux consuls se surveillent étroitement et chacun tente d'arrêter les activités de l'autre. De cette façon, 
pendant les premières années $\mathrm{du} \mathrm{XIX}^{\mathrm{e}}$ siècle, Sinop vécut une période de "diplomatie provinciale » créée par la présence des consuls français et russe dans la ville.

Après l'exil de Tayyar Pacha à Sohum, tout l'équilibre en Anatolie a changé. Pendant la domination de Tayyar Pacha dans la région, Fourcade a seulement dû essayer d'établir une bonne relation avec lui pour favoriser le commerce français; mais après 1805, le pouvoir à Sinop est multiple. Dans cette situation, l'agitation qui régnait en Anatolie après l'exil du Tayyar Pacha fut un véritable obstacle pour les plans du consul. En outre, le consulat a été attaqué par des marins grecs sous protection russe, en 1806, alors que Fourcade était à Kastamonu. Mais l'agression de 1807 a été plus décisive encore pour le consulat français à Sinop. Fourcade et le chancelier du consulat, Bernage, ont été sérieusement blessés par des marins lazes qui, ayant participé à la tourmente qui mit fin au règne de Selim III à İIstanbul, ont débarqué à Sinop en route vers leur patrie. Bien que l'expulsion de Sinop du consul russe, Konuchenco, après l'éclatement en 1806 de la guerre russe-turque, ait vraiment créé une "atmosphère de liberté » dans la ville, le rapprochement russo-français et le traité de Tilsit ont retourné cette atmosphère en Anatolie contre les Français. Ces nouvelles conditions qui apparaissent clairement dans l'agression de 1807 montrent aussi le peu d'avenir de la mission de Fourcade à Sinop.

Bien dont Fourcade n'ait pas obtenu de résultats significatifs pour le commerce français, son consulat de six ans nous a laissé des documents très précieux qui se trouvent dans les archives du Ministère des Affaires étrangères français à Paris et à Nantes. Ces rapports consulaires et des récits de voyage détaillés sont des sources très précieuses pour l'étude de la côte méridionale de la mer Noire au début du $\mathrm{XIX}^{\mathrm{e}}$ siècle. Une partie d'entre eux ont été publiés, mais certains rapports n'ont pas encore été retrouvés ou localisés. Ce sont les activités archéologiques de Fourcade qui donnent au consulat de Sinop sa valeur scientifique, mais au-delà, les archives des six ans de son consulat nous fournissent de précieuses informations sur la situation de l'Anatolie dans la "période des Ayans " au début du XIX ${ }^{\mathrm{e}}$ siècle, l'impact russe sur la mer Noire et l'histoire des relations franco-ottomanes en mer Noire. Cette étude vise à faire une étude du consulat de Fourcade à Sinop en utilisant les ressources des archives françaises.

\section{INDEX}

Index géographique : mer Noire, Sinop

Keywords : Sinop, French consulate, Pascal Fourcade (1769-1813), Ottoman Empire, French trade, Black Sea, Consular reports, Nineteenth century, History, Diplomatic history, Commercial History

motsclesmk СИНОП, ФРАНЦУСКИОТ КОНЗУЛАТ, ФОУРКАД ПАСКАЛ (1769-1813), ОТОМАНСКАТА ИМПЕРИЈА, ФРАНЦУСКИ ТРГОВИЈА, ЦРНОТО МОРЕ, КОНЗУЛАРНИТЕ ИЗВЕШТАИ, ДЕВЕТНАЕСЕТТИОТ ВЕК, ИСТОРИЈА, ДИПЛОМАТСКА ИСТОРИЈА, ДЕЛОВНА ИСТОРИЈА

motsclestr Sinop, Fransız konsolosluğu, Fourcade Pascal (1769-1813), Osmanlı İmparatorluğu, Fransız ticaret, Karadeniz, Konsolosluk raporları, On dokuzuncu yüzyıllarda, Ticaretin tarihi, Diplomatik tarih, Tarih

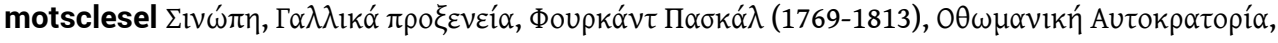

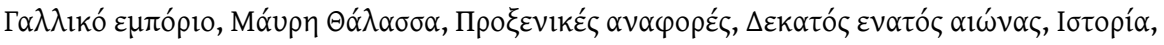

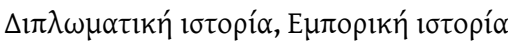

Mots-clés : consulat français, Fourcade Pascal (1769-1813), Fourcade Pascal (1769-1813), commerce français, rapports consulaires

Thèmes : Histoire

Index chronologique : dix-neuvième siècle 
AUTEUR

ÖZGÜR YILMAZ

Professeur d'histoire

Université de Gümüşhane - Turquie 